\title{
Foundations of Modernity
}

Human Agency and the Imperial State

\section{Isa Blumi}

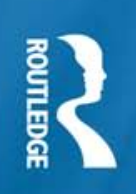


Foundations of Modernity 


\section{Routledge Studies in Modern History}

\section{Isolation}

Places and practices of Exclusion

Edited by Carolyn Strange and Alison

Bashford

\section{From Slave Trade to Empire}

European Colonisation of Black Africa

1780s-1880s

Edited by Olivier Pétré Grenouilleau

3. Revolution, Counter-Revolution and Revisionism in Postcolonial Africa

The Case of Mozambique, 1975-1994 Alice Dinerman

4. Charity and Mutual Aid in Europe and North America since 1800

Edited by Paul Bridgen and Bernard Harris

5. Churchill, Roosevelt and India Propaganda During World War II Auriol Weigold

\section{Genocide and Fascism}

The Eliminationist Drive in Fascist Europe Aristotle Kallis

7. Scientific Research in World War II What Scientists Did in the War Edited by Ad Maas and Hans Hooijmaijers

\section{Restoration and History}

The Search for a Useable

Environmental Past

Edited by Marcus Hall

\section{Foundations of Modernity} Human Agency and the Imperial State Isa Blumi 


\section{Foundations of Modernity}

Human Agency and the Imperial State

\section{Isa Blumi}


First published 2012

by Routledge

711 Third Avenue, New York, NY 10017

Simultaneously published in the UK

by Routledge

2 Park Square, Milton Park, Abingdon, Oxon OX14 4RN

Routledge is an imprint of the Taylor \& Francis Group, an informa business

\section{(C) 2012 Taylor \& Francis}

The right of Isa Blumi to be identified as author of this work has been asserted by him in accordance with sections 77 and 78 of the Copyright, Designs and Patents Act 1988.

Typeset in Sabon by IBT Global.

Printed and bound in the United States of America on acid-free paper by IBT Global.

All rights reserved. No part of this book may be reprinted or reproduced or utilised in any form or by any electronic, mechanical, or other means, now known or hereafter invented, including photocopying and recording, or in any information storage or retrieval system, without permission in writing from the publishers.

Trademark Notice: Product or corporate names may be trademarks or registered trademarks, and are used only for identification and explanation without intent to infringe.

\section{Library of Congress Cataloging-in-Publication Data}

Blumi, Isa, 1969-

Foundations of modernity : human agency and the imperial state / Isa Blumi.

p. cm. - (Routledge studies in modern history)

Includes bibliographical references and index.

1. State, The-History-19th century. 2. History, Modern-19th

century. 3. Social systems-History. 4. Middle East-History-19th

century. 5. Turkey-History - 19th century. 6. Mediterranean Region

-History -19 th century. I. Title.

JC201.B58 2011

$320.1-\mathrm{dc} 22$

2010048747

ISBN13: 978-0-415-88464-8 (hbk)

ISBN13: 978-0-203-81587-8 (ebk) 


\section{Contents}

List of Figures vii

List of Maps ix

List of Abbreviations xi

Preface and Acknowledgements xiii

Introduction: Relocating the Great Transformation in the Balkans and Arabia 1

1 The Local Scramble for Ascendancy and the Demise of the "Era" 15

2 Demarcating Imperial Boundaries and the Rise of Difference 48

3 Beyond the Frontier: Subduing the Agents of Change 78

4 Diasporic Agency and the Shifts in the Possibilities of Empire 110

5 Capitalizing Empires and the Political Economy of Reform 142

$\begin{array}{ll}\text { Conclusion } & 169\end{array}$

Notes 181

Bibliography 243

Index 265 


\section{Figures}

3.1 Refugees in Yakova/Gjakova Kosova circa 1910.

3.2 Malësor refugees in Shkodër, between 1880-1900. 97

$5.1 \quad$ Skopje Market after 1913. 


\section{Maps}

1.1 Arabia $1900 . \quad 32$

1.2 Western Ottoman Empire, 1877 (Prior to Berlin Congress). 46

2.1 Africa. 52

$2.2 \quad$ Border Areas, 1878-1912. 56

$2.3 \quad$ South-west Arabia, circa $1900 . \quad 60$ 


\section{Abbreviations}

ACS

AHR

AiT

AMAE

AQSH

ASMAE

ASMAI

AUSSME

BBA

CP

$\mathrm{CSSH}$

DDF

DDI

DH.ID

DH.MUI

DUIT

EIC

$\mathrm{FO}$

HAT

HHStA

HR.MKT

HR.SYS

IJMES

IJTS

IMRO

IOR

MAE

MV

PA

PR

PRO
Archivio Centrale dello Stato

American Historical Review

Ambasciata d'Italia in Turchia

Archives Diplomatiques de Ministère des Affaires Étrangères

Arkivi Qendror Shtetëror

Archivio Storico del Ministero degli Affari Esteri, Serie Affari Politici

Italian African Bureau

Archivio dell'Ufficio Storico dello Stato Maggiore dell'Escercito

Başbakanlık Osmanlı Arşivi

Correspondence Politique

Comparative Studies in Society and History

Documents Diplomatiques Français

Documenti Diplomatici Italiani

Dahiliye Nezâreti Idare Kismi

Dahiliye Nezâreti Muhâberat-ı Umumiye

Dosya Usulu Iradeler Tasinifi

East India Company

Foreign Office of British Government

Hatt-1 Hümayun

Haus-, Hof- und Staatsarchiv

Haricye Nezâreti Mektubi Kalemi

Haricye Nezâreti Siyasi

International Journal of Middle East Studies

International Journal of Turkish Studies

Internal Macedonian Revolutionary Organization

India Office Record

Ministeri Affairs e Estare

Meclis-i Vükelâ Mazbatakları

Politisches Archiv

Political Resident

Public Records Office at Kew Gardens 


$\begin{array}{ll}\text { SAP } & \text { Serie Affari Politici } \\ \text { SHAT } & \text { Service historique de l'armée de terre } \\ \text { SNA } & \text { Swiss National Archives } \\ \text { TFR.1 } & \text { Rumeli Müfettişliği Tasnifi } \\ \text { TFR.1.KV } & \text { Rumeli Müfettişliği Tasnifi Kosova } \\ \text { TFR.1.ŞKT } & \text { Rumeli Müfettişliği Tasnifi Arzuhaller } \\ \text { YA.HUS } & \text { Yıldız Tasnifi: Sadâret Hususî Mâruzât Evrakı } \\ \text { YA.RES } & \text { Sadâret Resmi Mâruzât Evrakı } \\ \text { YEE } & \text { Yildiz Esas Evrak } \\ \text { Y.MTV } & \text { Yıldız Tasnifi: Mütenevvi Mâruzât Evrakı } \\ \text { YA.HUS } & \text { Yıldı Tasnifi: Sadâret Hususî Mâruzât Evrakı } \\ \text { Y.PRK.MŞ } & \text { Yıldız Perakende Evrakı Meşihat Maruzatı } \\ \text { Y.PRK.MYD } & \text { Yıldı Perakende Evrakı Yaveran ve Maiyyet-1 Seniyye } \\ & \text { Erkan-ı Harbiye Dairesi } \\ \text { Y.PRK.UM } & \text { Yıldı Perakende Evrakı, Umum Vilayetler Tahriratı }\end{array}$




\section{Preface and Acknowledgements}

For those with any sense of historic perspective, the way our world has mutated since World War II—and especially after 9/11—must seem like a cruel joke. Beyond the clichés that "history repeats itself" is the insertion of a meta-narrative of History into applications of power that frustrates, disorientates, and finally angers. After all that has been done in the last thirty years to collapse the arrogance of "Western" epistemologies about how the world is divided between "civilized" and "primitive" peoples, after all the work to confront power in its various forms-military, institutional, culturally, and intellectually-we are back to square one.

Today, politicians make the necessary xenophobic gestures with impunity. "Different" peoples with easily identifiable "traits" are the focus of a never-ending barrage of innuendo and very real persecution. These darkskinned peoples who dress "different" are easy targets for a political order desperate for diversions. Amid all of this, most of my colleagues and I have run to the safety of the academy. Sitting, watching outside our office windows, cowering as the world collapses onto itself, we just sit and hope the "robo-audits" do not take our homes away.

The irony is, as some would think Marx predicted, the destruction of the American and European Middle Class we are witnessing today is a by-product of the inherent contradictions of this "Modern" world. A world driven by a capitalist system, the fundamentals of which are so obscure that even the armies of MBA's now toiling to make ends meet fail to understand just for what do they work. But as the self-anointed "West" begins to rip apart with the richest 0.01 percent taking the spoils while everyone else is left in debt and faced with a menace of fascism, war-mongering, and the politics of fear, the way forward proves impeded by a debilitating failure to understand the past.

This is the context in which I finalized this book. It started, however, under very different pretexts. In fact, it started before it was ever imaginably a book. In this respect, the "book" goes back to the incubator called the New School for Social Research. It is there that Professor Ferenc Fehér first introduced me to Louis Althusser, whose work contributed so much to the final development of my project. The period between then and now constitutes many hours on planes, no doubt years of my life sitting down in archives and countless more typing away, digging through dictionaries, losing files, 
patience, loves, and yet, I just went back for more. In the process, my life has been transformed by the people with whom I have shared this toil.

In expressing my gratitude to those who have helped me with this undercompensated life, I admit the words I conjure up here fail to adequately express what everyone's contribution has been. That being said, I can safely say my beautiful wife-Dardane Arifaj-who has only known me for half the life of this book, has already seen my better half pass away, many many drafts ago. We met because of the work I put into this book and for that, she has made me something other than this book, and for this: te dua, SHUME, Daki.

My mother has once again left me with more than I can possibly embrace. Her sacrifice and her insanity have made me possible. Without her strength and without her love, this all would be meaningless. Amid this familial insanity is Rrugac. My beautiful little man . . . your feet are all over this one.

Love and thanks go to my Kosovar family; may we continue to thrive together. In this vein special thanks goes to Visar for helping with the images and maps, again.

I dedicate this book to Istanbul, my home, my true home. Istanbul, you have brought me endless material for life. I have met beautiful souls within your walls, and I dedicate this to you and for those who have lived in that empathetic place as it has long been designed. May you last another thousand years.

One of the cornerstones to Istanbul is Ebru Sönmez (and Pasha), to whom I am indebted for all their companionship and support.

And then there are the new friends, those who actually weaved their way into the very words of this book, whose interest, shared compassion, and indignity all translates into an enduring friendship, and perpetual gratitude for being there when I need you. Jon Schmitt, this must be the start of years of collaboration and perhaps changing something. But just do not forget, ART is the only real way out. You my friend, have the map. Keep it, it is yours. Casey and Michelle Lacoss too, have proven to be adults amongst the posers. They too will find greener pastures if I have anything to say about it. But they will have to jump the Atlantic, like me, in order to find them. I also wish to thank most sincerely the last minute assistance from Robert Baker, Teija Korhonen, Alex Manavi, and Cheryl L. Nye.

The research conducted to make this book's complicated argument could not have been conceivable without my experiences at the New School for Social Research. It was an honor to have had the opportunity to work with Aldo Lauria-Santiago, Talal Asad, Eric Hobsbawn, Ferenc Fehér, Aristide Zolberg and Charles Tilly; I thank all of them for having such a life-long impact on the way I interact with the world. My nine years of affiliation with New York University also proved crucial. Zachary Lockman deserves most of the praise and will forever be my model for being decent and human to colleagues and students alike. I am also extremely grateful to Frederick Cooper, Maria Todorova, Khaled Fahmy, and Ruth Ben-Ghiat for sharing their time with me as I wrote the dissertation and then again, whenever I needed to share ideas. Again, I have been so very fortunate. 
Research over the years was made possible by the contributions of so many: Aras Gaylani, Thomas Kühn, Ryan Gingeras, Ayten Ardel, Nicole van Os, Jens Hanssen, Sabri Ateş, Carole Woodall, John Drabble, Maurus Reinkowski, Stefan Weber, Sinan Kuneralp, Andras Riedlmayer, John Chalcraft, Rifat Abou El-Haj, Stacy McGoldrick, Gail Kligman, Béatrice Hibou, Jean-François Bayart, and Florian Bieber stand out. For Edith and Josef in Vienna, Greg and Sasha in London, Ussama in Beirut, Ahmed in Cairo, Francesco and Yoav Di-Capua in Rome, Bettina and Ka in Bern, Andrea in Paris, Cis, Maryte/Fred/Mickey, Mary-Beth, Ewa, Peter, Cornelia and Vicky in New York, and Shawn in Washington, your hospitality and generosity helped me access the documents otherwise inaccessible. And Frank Shouldice, you are a man amongst boys.

Musëmma Sabancioğlu cared for Rrugac, and proved very kind and diligent in working with me on this book. Thank you. Thank you Joe (Jack) Perry and Joyce and Puss for the incredible evenings in Atlanta; without those extra long sessions in midtown, what would I have been able to accomplish? Richard Gassan, thanks for being yourself. To Neema Noori and his amazing family, the Matador has always a place at the table for you. John Curry out there in Vegas, you must know some of this by now! Thank you for the years of friendship. Steven Hyland and family, much love and Michael Hamson and your family are always part of what I do.

Colleagues and students starting from Trinity College in New Haven, the American University of Sharjah and Georgia State University where I have taught during the writing of this book contributed greatly to both the delay in its completion, and its inevitable improvements. I send my particular thanks to Bassel Salloukh, Ghulam Nadri, Michelle Brattain, Larry Grubbs, Jared Poley, Christine Skwiot, Michele Reid, Douglas R. Reynolds, Nick Wilding, Hugh Hudson, and Larry Youngs. I also thank some great students at GSU who have kept me alert to the many things I should be striving to do to make this world more liveable. At AUS, a warm thanks to Dr. Winfred Thompson for allowing me to teach basketball and retire undefeated. Also to Dr. Nada Mourtada-Sabah, it was an amazing opportunity there at AUS, with wonderful students and I now appreciate it with great fondness.

To my new colleagues and friends at the Centre for Area Studies at Universität Leipzig, a warm thanks for the space to work this out. Dr. Matthias Middell has done a wonderful job working to put this meaningful project together. With the generous funding of the Bundesministerium für Bildung und Forschung, I have been able to come "home." A special thanks goes to my colleagues Markus-Michael Müller and Nadine Sieveking for their comments on earlier drafts. Martin Heckel and I have a date in the slums. And then there is the glue that has kept all of our lives in order, Antja Zettler; vielen Dank!

I wish to extend my greatest appreciation for a wonderful editorial partnership at Routledge USA; Laura Sterns in particular for the trust and support she invested in this book, even when my "colleagues" proved less than collegial. Dear Laura Sterns, who bravely pushed and pulled for the early manuscript to 
find a reader deserves the right to tell me what is this project's best title. But Foundations? In some interesting ways I hope she picks up on when reading it, I now suspect she understood what I was after before I was fully aware. That title Foundations of Modernity was a real roadblock for me; it twisted my ideas in such a way that I still cannot really say what I mean; but I have worked with Laura's inspiration and it has pushed me deeper into what it is I needed to do with all these years of work. Thanks also goes to the great Stacy Noto, patient and ever supportive, may there be plenty of trips to beaches and Berlin in your future. I have been blessed by you guys; I look forward to doing it again one day. When you are ready for my proposal, let me buy the first round. I wish to also thank Michael Watters of Integrated Book Technology, Inc. for his willingness to integrate my frequent changes to the text, a thankless task from which I have reaped the rewards.

I also need to send my kindest regards to the anonymous reader whose comments and encouragement, I hope, was not wasted with this complete revision. Your comments have shaped a project that had something else destined for it. I look forward to buying you coffee and hearing what you think.

I wish to acknowledge the professionals who helped facilitate my extensive research throughout Europe/Middle East. In particular I want to thank the staff at the Arkivi Qendror Shtetëror in Tirana, Haus, Hauf und Staatsarchiv in Vienna, the former Politisches Archiv des Auswaertigen Amtes der Bundesrepublik Deutschland in Bonn, Centres des Archives diplomatiques de Nantes/Paris, Archivio Storico del Ministero degli Affari Esteri in Rome, the Başbakanlık Arşivi in Istanbul, the Public Records Office at Kew Gardens, the National Archives in Maryland and finally the Atatürk Library in Istanbul. Special acknowledgement must be given to the organizations and institutes that have provided generous funding to help research and write this book: The Fulbright-Hayes Committee, American Council of Learned Societies, the American Research Institutes in Turkey and Yemen, CAORC and the Social Science Research Council contributed generously to my research all over the world.

Finally, a brief explanation of the terms and spelling of geographic locations is in order, especially in respect to the Balkans. As this book's fundamental agenda is to argue that there are different ways to interpreting events in the world before Modernity, I have been particularly keen on demonstrating this by adopting terminology that reflects regional variety. In other words, I utilize place names and spellings on several occasions throughout the book that are normally not found today in English. I employ these spellings interchangeably with the more conventional place-names and their spellings to highlight the fluidity of identity claims and associations among people living in the western Balkans at an earlier time. This is most often done for "Albanians" whom I refer to in their Ottoman characterization-Arnavut/Arnavutlar (pl.) - because this compels the reader to be conscious of possible shifts and distinctions. I trust this will not be too confusing. 


\title{
Introduction \\ Relocating the Great Transformation in the Balkans and Arabia
}

\begin{abstract}
A critique is not a matter of saying that things are not right as they are. It is a matter of pointing out on what kinds of assumptions, what kinds of familiar, unchallenged, unconsidered modes of thought the practices that we accept rest ... Criticism is a matter of flushing out that thought and trying to change it: to show that things are not as self-evident as one believed, to see what is accepted as self-evident will no longer be accepted as such. Practicing criticism is a matter of making facile gestures difficult.
\end{abstract}

Michel Foucault "Practicing Criticism"1

Scholars of all disciplines regularly accept as common knowledge that the nineteenth and twentieth centuries represent the apex of "European" hegemony. ${ }^{2}$ Fascinated by the scope and pervasiveness of such an accomplishment, readers are reminded that we can measure this European power not only by the number of "subalterns" killed, exploited, and denigrated. The world's commercial networks, claimed to be diligently regulated by a codified standard of law, a pervasive standard of high and low culture, or the predominance of certain kinds of governmental institutions and practices, also are mobilized prodigiously in the historiography to suggest a dramatic caesura in human history that emanates from "Europe." ${ }^{3}$ The point is often made more poignant by the plethora of detailed statistics that highlight Europe's material ascendancy and its subsequent, increasingly ambiguous, legacy on colonized cultures. Not merely descriptive, these documented "facts" of both genocide and humanism are also used to instil the impression that Europe physically and epistemologically dominated the world, in effect creating the world in which we are all now living as either hapless beneficiaries or victims. ${ }^{4}$

This world analytically framed to concede the past to the forces of globalization is, however, a discursive phenomenon, an ideological project, a myth. The work that follows will mobilize a number of disparate scholarly voices to disassemble this pernicious mythology. In the course of adopting what is ultimately a revisionist methodological approach, Foundations of Modernity suggests another orientation is possible when exploring both theoretically the confines of our contemporary world, and the means by which we can correct perceived injustices inherent in it. At its core, the following proposes 


\section{Foundations of Modernity}

to engage with the dominant concept of "Modernity" as an extension of "European" power and thus confront a persistent assertion that we can only understand our "European-dominated" world through this conceptual prism. The central problem is that "Modernity" (from now on, I drop the quotation marks but acknowledge its hegemonic pretensions by keeping it capitalized) in many ways subsumes all our ability to actually discuss "alternative" realities. This Modernity operates in its own kind of "sublime," ideological order beyond the corrective machinations of subversive theory and actual "facts" on the ground. ${ }^{5}$ As such, the centrality of Modernity in the way we discuss the past and present means it resists deconstruction, and thus critique. Indeed, whether acting as an instructor using textbooks marketed to English-language undergraduate university students or monitoring events in the mainstream or alternative media, one finds that, despite recent efforts to refashion these surveys to be "more inclusive," Europe remains the destructive (and thus generative) force in the post 1789 period. ${ }^{6}$ In other words, this Modernity (a.k.a. "the West") is a transcendent truth, one that interweaves patterns of domination and exploitation with forms of presenting our past, present, and future. ${ }^{7}$ The collective failure to disentangle the components of these hegemonic discourses has thus left academic "knowledge," much like corporate media and government propaganda, implicated in the social construction of subordination-as-reality.

From this perspective, Foundations is both an account of and an intervention in a process of epistemological mutation that has really only taken on its hegemonic properties since World War II. At its heart, therefore, this study challenges the assumptions of a rational, progressive, and teleological historical development that have long been associated with Modernity-what is today uncritically accepted as an irresistible historical force, as opposed to merely a post-WWII trope-by introducing a dynamic set of cases within and along the fringes of the Ottoman Empire and its many competing interlocutors in the larger Eurasian, Indian Ocean, and Mediterranean regions. Far from helping reinforce the generic binary constructs that still assert as given truths the "Ottoman Empire" as the consumed opposite of "the West," the primary purpose of using a comparative and contrastive study of events in the Balkans, Red Sea, and Persian/Arab Gulf regions is to highlight just how unrepresentative the meta-narrative of Modernity is in the context of several different pre-WWI worlds. ${ }^{8}$ Put differently, rather than being a mere subordinate to a "western" story of ascendancy, the dynamic territorial edges of the Ottoman Empire, let alone its core in Istanbul, prove to be ideal sites for the analysis of complex, interdependent exchanges between indigenous and external actors.

\section{IDENTIFYING NEW SOURCES OF CHANGE}

Rather than concede that the modern forms of power we see today are inevitably part of everyone's past, Foundations actually situates the discussion 
along the grid of exchange that proves more than likely to have actually induced certain adaptations in the way states and their masters interacted with indigenous agents of history. As demonstrated in Chapters 1 and 2, despite assertions that this was a time of conspicuous state centralization, the period from 1800 to 1875 really marks a power vacuum in terms of actual states' capacities to manage events. The Ottoman Empire and its many external imperial adversaries and/or allies often would be forced to adopt and adjust the way they used institutions as local contingencies initiated any number of crises. Such variability to the day-to-day performance of the imperial state frequently resulted in a considerable shift in the distribution of power and the introduction of entirely new constituencies into the inner-confines of the state.

It is important to stress that identifying this process with just a sampling of cases found throughout the archives implicitly revokes the accuracy of the hegemonic narratives of Modernity found in the scholarship today. Cases drawn from the Ottoman borderlands prove the British, French, Italian, or Russian empires were still sitting precariously on the margins of many different worlds while the peasants, refugees, merchants, sailors, and urban poor of the Ottoman Empire had as much leverage in world affairs as those today celebrated in the historiography as "founding fathers."

The forces at play that drove these respective societies towards an organization of institutions we have since associated with the modern empire/ colonial state had their origins in the intersections of many other possible human trajectories. These are the "Foundations" to which I refer in the title of this book. They constitute the ruins of all those other human potentialities on which those who evoke Modernity rest their hegemonic claims.

As a kind of taunt to those who so arrogantly claim such authority over the past, I highlight the capacities of various peoples to organize, engage, and ultimately resist nineteenth century state power. Chapter 2 begins this insubordinate gambit by suggesting that much of the immediate aftermath of the formal occupation and direct administration of three different regions (Western Balkans, Red Sea/Persian Gulf littorals) entailed a complicated series of adjustments that went beyond the issue of simple physical control to methods of dealing with a range of local reactions, adjustments, and socio-economic shifts. In time, the methods of incorporating each of these regions into the larger "global order" via diversified social engineering schemes ultimately led to programs of territorial and ethnographic abstraction usually known today in terms of the "frontier."

Events in the Western Balkans and the larger Red Sea and Persian Gulf littoral suggest there may be another way of understanding the remarkable transformations associated with the rise of the modern world. ${ }^{9}$ Rather than reading the experience of European (or) Ottoman imperialism as monolithic, and thus playing their rigid, fixed roles in the eurocentric teleology, it may be useful to highlight just how dramatically different the experience of the nineteenth century was for so many different peoples located at the intersections of these supposedly distinct historic 


\section{Foundations of Modernity}

entities. What, in other words, the following work intends to make clear is that populations living within three "peripheral" districts of competing empires-the Ottoman, Russian, Austro-Hungarian, British, French and Italian-all conformed to different (and often fluid) social orientations, what could be called contingent positions, that render the social scientific typologies informing our conventional notions of the hegemonic Modernity inadequate and ultimately silent. ${ }^{10}$

Using the above assertion as an ingress, we will not only argue throughout that modern imperialism took on quite different forms depending on time and place, but an even more important general claim will be made that the kind of exchanges taking place in these "local" contexts were eminently consequential to the very development of the state system, bureaucracy, and socio-economic patterns we associate today with Modernity. What makes this intervention unique in contemporary historiography is that it proposes that the consequences of these interactions-which in complicated ways, actually laid down the Foundations for much of what today some want us to believe are the roots of Modernity-may never have been intended to have such a direct impact on the larger world.

And this is the essential point: Modernity's teleological meta-narrative would have us believe that the modern world as we know it today existed in some nascent yet still programmatic and articulable form over the course of the long nineteenth century; all that was necessary-and certainly irresistible-in this telling was an incubation period of brute force and coercion during which already languishing, "backwards" societies would be brought up to the speed of civilized "Europe." This narrative, however, does not hold up under scrutiny. In fact, a rigorous vetting of the documentary evidence (one that does not commence with the presupposition of an inevitably ascendant Modernity) shows that the administrative projects aimed to control human contingencies, known today as governmental formulas levied by the "Great Powers" and the Ottoman Empire, were far from mediated by a coherent, systematic project intended to enact a "modern" world. It must be stressed that constant adjustment to contingencies "on the ground," taking the form of appeasement and conciliation to local power-holders, and recalibrated as administrative policy, were the requirements demanded of these states in an effort to stake even modest claims in "peripheral" areas like the Western Balkans and Arabia.

In the final analysis - if that analysis is freed from the straitjacket of Modernity's tropes-the social, economic, and political acumen of these indigenous, peripheral "subalterns" often dictated the terms by which the Ottoman statesmen and their European equivalents played the geo-political game. Accepting this premise, the "foundational myths" of Modernity, as purportedly materializing during the long nineteenth century, may be effectively "re-mapped" as having completely different-and often counter-intuitive-cardinal points than we are conditioned to perceive today. ${ }^{11}$ In other words, this book offers a methodological intervention meant to 
challenge conventional studies of the modern era that are flattened out by the general study of an empire or an assumed range of interests based on class, sectarian, or ethno-national associations. ${ }^{12}$

Expressed in these terms, this book differs from other comparative empire studies in that it treats the events in the vast and diverse Ottoman Empire as the origin of much of the modern world's transformations, as opposed to being a mere reflection of them. This reassessment reveals that local exigencies shaped and changed the absolutist agency of the imperial state, an insight that requires a trans-regional, comparative, and interdisciplinary approach. At the core of the arguments made here is thus an understanding of the reciprocal relationship between state institutions and subject populations. This builds, in principle, on recent reappraisals of postcolonial theories of the modern world by emphasizing the "collaborative" dynamic of imperialism.

This constitutes what anthropologist Tsing phrased the effects of "friction." 13 The periods of "friction" or exchange between still balanced stakeholders in indigenous societies and those representing private finance all created "zones of awkward engagement" where capitalist interests increasingly reshaped the landscape of the "traditional" world (which included huge swaths of rural and urban "Europe" and North America, by the way) not so much by program and the force of "progress," but by constant conflict, struggle, and negotiation with locals. ${ }^{14}$ The rich terrain in which these interactions (causing productive "friction") took place constantly reanimated both the local and the many external forces involved. The results of such exchanges, I suggest, would be variables of the "modern" state that, through trial-and-error and different types of applications of "governmentality," became some of the Foundations post-Ottoman propagandists would claim. It is along these "zones of awkward engagement" that I suggest we ultimately need to analyze a world prior to the possibility of Modernity.

A central methodological task is reconfiguring how we understand the practical consequences of peoples' complicated experiences of being uprooted by various social, natural, and political forces. At the forefront of this repositioning of, for instance, the refugee as an agent of the past, are the communities in which refugees settle. Taking the perspective of the local host community, the villagers and their extended network of trading, cultural, and bureaucratic partners distributed in the immediate area, it is clear that they are directly impacted by the influx of destitute refugees. This is not a simple story however, as it constitutes a dynamic fraught with tensions that are virtually ignored in the scholarship that seems to not see any ill-will generated by refugees. ${ }^{15}$

In this attempt to excavate other Foundations from our multiple pasts, the study undermines the putative roles certain "types" of peoples are destined to play, especially when they are put in assumed "conditions" that in their very nature position them-rural poor, slaves or "refugees"—outside historical 
agency. In this respect, if we theorize those much invoked "objects of history" like the refugee who are rarely treated as agents themselves, it may then be possible to recognize a prominent role for human beings otherwise trapped in the hierarchical dynamics of eurocentric and subaltern orientated studies. ${ }^{16}$

This book also examines other important perspectives of the local and central Ottoman government activities. In this respect, the refugee in an imperial setting during the last quarter of the nineteenth century is perhaps the quintessential target for governmental management. Dispersed refugees, without home and most often without more than the clothes on their backs, would in theory have been easy targets for the modern empire eager either to "colonize" or manage such hapless "victims." According to some interpretations of the nineteenth century state, the very fact that people were mobile and not settled was necessarily anathema to the generic "modern" state. ${ }^{17}$ This reading is entirely reasonable considering the sources. If, for example, one were to resort to reading only the secondary literature, the most likely conclusion indeed would be that refugees flooding into the Balkans in the 1870s and throughout Eastern Arabia in the 1890s were confronted by a well-tuned bureaucratic apparatus that mastered the management of human beings.

Much of the scholarship on the Ottoman reforms points out that by the 1850 s there were government agencies charged with adjudicating just these kinds of situations. In fact, facing the onslaught of tens of thousands of Mus$\lim$ Slavs and Chechens as a result of the constant violence along the shared Ottoman-Russian frontiers, a new program of integration, including issuing citizenship documents, had been developed. ${ }^{18}$ Following the introduction of various immigration laws, in 1859 the Ottoman state appears to have created a committee for the management of migrants-Muhacirin Komisyonu-to pool regional government resources to help settle peoples uprooted by the Crimean War. Scholars impressed by these bureaucracies claim that such committees would continue to function until the end of World War I, distributing resources and issuing orders for the systematic resettlement of refugees throughout the vast empire. ${ }^{19}$ The problem is, as shown throughout, the mechanisms look fine on paper, but rarely translated well on the ground.

As Chapter 3 points out, the many agencies within the state simply did not have the means to contain these mobile and desperate peoples within neatly defined administrative schemata. Rather than being malleable objects susceptible to bureaucratic manipulation or just grateful for attention, refugees proved far more difficult to "manage" and often created entirely new channels of disruption that forced a variety of administrative agencies to change the way they conducted their daily affairs. Put differently, the refugee, presumably the most vulnerable and weak historical agent, proved to be outside the capacity of the Ottoman and Great Power bureaucracies to control. While recent scholars have attempted to highlight the capacities of the Ottoman state to influence the lives of so many uprooted people via "citizenship" laws, taking a close look at the 
day-to-day affairs on the ground helps one realize that this scholarship fails to explain actual implementation. ${ }^{20}$

As I explored the wide range of documentation available for the period between 1800 and 1912, it became clear that refugees were not some docile aggregate under the façade of the centralized government highlighted in the literature. Much like the communities found living along new frontiers "imposed" by different forces as explored in Chapters 2, 3, and 4, rather than being a passive recipient of state largess (or oppression), the refugee co-existed with numerous other stakeholders beyond the very "political and economic calculations" deemed by Timothy Mitchell to be the primary innovation of the mid-century state. ${ }^{21}$ The refugee, in other words, was not entirely accessible to the state, despite the often elaborate efforts to apply what Foucault classified as "subjection" (subjectification) in order to influence the refugees' ever-shifting associations. ${ }^{22}$ Other factors besides an amorphous state contributed to the changes retrospectively associated with Modernity

In the period covered here, fundamental changes in the way states instituted laws and regulated commerce also reflected the integration of new forms of administrating production in the larger world. This then suggests a role for private finance. The fact that so many of the issues surrounding refugee settlement in the Balkans prior to 1912 were linked to land, the dynamics of "market" forces, and the intensive investment into Balkan (and Arabian) lands for financial gain animated the story of empire and the modern state in very different ways. Here too, the kinds of "subjection" Foucault identified as crucial to the imposition of modern power were evident in the Balkans.

In much of the scholarship the appreciation of land values, coupled with the rush to "invest" in land proved to put interesting pressures on the ability of temporary communities to sustain internal cohesion in the face of the many forms of "individuation" that are synonymous with Modernity. Put differently, the fragmentation of communities as a result of conflict over values, needs, and ambitions represents the single biggest force in destroying the human community through Modernity. Indeed, as revealed in many studies, the alienation experienced by peoples around the world as they faced European finance capitalism served as the key wedge in destroying communal integrity. ${ }^{23}$ In cases discussed at length in Chapter 5, however, capitalization of land was still not yet fully enforceable.

The corrupting influence of hindsight has convinced many scholars-both conservative and progressive-of the inevitability of the Ottoman Empire's fate vis-à-vis a generic "West." A deeper inspection into the entire nineteenth century, however, suggests the need for more nuance to situate what impacted the interactions between "failed empires" like the Austro-Hungarian and Ottoman and ascendant global powers of the first-half of the twentieth century. The underlying conclusion drawn from this study is that modern imperialism was not yet a refined machine imposing unchallenged dictates upon 


\section{Foundations of Modernity}

the rest of the world. ${ }^{24}$ As described in Chapters 1 and 2, the very modern institutions, methods of diplomacy, and territorial abstractions synonymous to European hegemony, are actually by-products of local processes that took decades to play out. Moreover, within certain local contexts, these evolving methods of modern state rule offered a range of possible directions for an ever-shifting set of constituencies that only complicated the ambitions of, among other components of modern power, global finance. In the end, the modern principles of law, territoriality, and social rights within the parameters of a neatly defined state may just be the markings of long-standing resistance to imperial rule, contingencies created by the most humble of actors. ${ }^{25}$ Put differently, the often subjugated, enslaved, terrorized, and objectified natives prove far more central to the modern world than even the most sympathetic historian of the "subaltern" is willing ideologically to concede. ${ }^{26}$

Not prepared to write histories under the shadow of what is nothing more than a scholarly trope concocted after World War II, I will reconstruct multiple, often disjointed, parallel pasts of indigenous agents long assumed to exist on the periphery of the modern world in order to complicate our thinking of the "Foundations" of Modernity. In the end, such an exercise will expose Modernity as nothing but another tendentious ontological assertion about the "West" by those who see themselves of the "West." ${ }^{27}$ As such, this totalizing myth proves to be completely irrelevant to reading events in periods and places long assumed directly transformed by Modernity. In the process of interrogating Modernity by presenting the Ottoman Empire and the incumbent themes usually associated with "it"-Islam, ethno-nationalism and capitalism - this study aspires to initiate new ways to talk about the world's multiplicity, beyond (before) the frame of Modernity. ${ }^{28}$

As is the case with most revisionist work, it is acknowledged that in order to accomplish a sensitive reformulation of the kinds of change associated with hegemonic epistemologies, like Modernity, one must step beyond the literature of "the field" (in this case Middle Eastern, Balkan, or Ottoman studies) and consult as much research as possible that has represented the past in entirely different terms. In this inherently interdisciplinary mode, one can find a different set of possibilities for many of the human beings involved in this experience of empire and the purported "rise" of the modern world. ${ }^{29}$ Unfortunately, these complex interactions are often framed in terms of disaggregation (and conflict) from what are conceded to be distinctive forms of socio-political organization. As a consequence, much scholarship continues to rely on misrepresentations that perpetuate the idea of there being something particularly distinct about Europe as an essential source of change.

Writing beyond the scope of Modernity itself, (again, a post-WWII operating logic) the events described throughout this book are meant to suggest a similar detachment from a Eurocentric epistemology. Charting a series of events involving many different people living in completely different corners of the world, we need to reconsider how one can observe processes that ultimately laid the Foundations for the institutional, epistemological, 
and political economic transformations later interpreted as Modernity. ${ }^{30}$ Asserting that these events have no meaningful relation to our very contemporary world, hence cutting analytical links distorting and disruptive post-WWII "Western" epistemologies make, may enhance our ability to actually engage the past. ${ }^{31}$ The purpose of this exercise, in other words, is to disaggregate, disentangle, and free the past from our present and future in order to explore alternative sets of explanations for the foundations of our modern world.

In surveying the literature on the period from 1750 to 1914 , one is struck by how little European domination, reduced to fit within the categories of Modernity, is ever questioned. To historians both sympathetic to the paradigm of European ascendancy and those concerned with the consequences, a full understanding of the numerous social, economic, and political pathologies of our human condition is often limited to a study of the effects of European imperialism as understood since WWII. ${ }^{32}$ Endless accounts have been written concerning the overriding influence (both negative and positive) of the steam engine, the advancement in European weaponry and military strategy, transport technology, and accounting techniques. These studies imply in some rather troubling ways that such "progressions" constitute direct links along a linear track between our realities and the past. No matter what it is we want to study in the past, in other words, we ultimately surrender to periodizations that affirm our present/future (framed in terms of Modernity) as well as end up situating, somewhere in the story, the monolithic White Man, whose omnipresence in "history" influences both our ability to write a narrative of resistance or question the very source of "western" knowledge. ${ }^{33}$

Disaggregating the events taking place in regions that today seem to have a direct bearing on our world may result in a new appreciation for just how disjointed and ultimately disconnected Modernity is from historical experiences long presumed to be necessary extensions of the Western story. Moreover, as an ultimately ethical gesture to those who had to engage the world through the prism of an inevitable "Europe," I argue it is possible to undermine the very structure of power which sits atop the trope of Modernity today by simply not acknowledging it historically. That is to say, I do not so much want to mount a direct attack on Modernity, but rather aim to drown out its pretensions by restoring the voices of those it has long been mobilized to silence. This goal, in the end, intends to complement the pursuit first initiated by Louis Althusser and Talal Asad, followed later by others.

\section{IDEOLOGICAL/THEORETICAL FOUNDATIONS TO STUDY}

Central to this revisionist exercise is a project to build on and expand beyond the work of progressive scholars unhappy with the way we write 
and talk about the world. At the heart of their critical work was the impact of classic Hegelian/Marxist historicism and the disruptions that the lingering orthodoxy caused in truly breaking from the rationalizations of Western imperialism. The work of Edward Said perhaps best articulated these concerns. Throughout his career, Said exposed the paradox of "Western" hegemony infiltrating the very critical work aimed at undermining the historicist premises of Western imperialism's apologists. ${ }^{34}$ The "West," as ideal object of both a critical rereading of History, or the celebration of western liberal democracy, ultimately reinforced the same epistemology. ${ }^{35}$ Herein lies this book's primary challenge.

Trying to write out of the grasp of the meta-narrative of Modernity, as Edward Said and, more recently, Timothy Mitchell have demonstrated, is theoretically impossible from within the conventional paradigms of the progressive left. ${ }^{36}$ For all the claims of resistance, from Frantz Fanon to Jean-Paul Sartre, the anti-Western warrior constantly resorted back to a totalizing knowledge that was trapped by a History (capital H) that centered "Europe" as the final source of both oppression and liberation. ${ }^{37}$

Barely old enough to appreciate the debates that still raged in the 1980 s when I was an undergraduate student, I too fell victim of fetishizing the Marxist dialectic and Sartre's existentialism. In time, however, this changed with the realization that so much of what today we project as subversive is predicated on a limited appreciation for the problems created by loyally working from methodological frameworks-especially Marxist and Foucauldian-that are themselves entrenched in a "European" tradition. ${ }^{38}$

It is possible, however, to step out of this epistemological cage. While trying to figure out how to integrate my work on "the Ottoman Empire" with the innovative strategies of Talal Asad, a chance rereading of Louis Althusser suddenly opened a new perspective to our fundamental problems. ${ }^{39}$ Coupled with the recent challenges posed by Frederick Cooper to comparativists and historians of colonialism everywhere, I am convinced that it is possible to write beyond Modernity. ${ }^{40}$ More importantly, it is possible to do so in a way that still meaningfully contributes to our continued quest to bring complexity to the modern era as well as usefully engage in an ethical manner the people of the past, many of whom so bravely stood up for what today seem like forgotten principles of common decency, love of family, and honor. ${ }^{41}$

It all starts with Louis Althusser. Althusser's well known break with Marxist orthodoxy in the 1960s took him beyond History to begin to conceive of the past that takes place not as a single overarching narrative-the Western History-but as an intersection of "networks." 42 These networks, what I will call local histories for the sake of simplicity, are everywhere in the documentation. This is in itself no surprise to any decent historian. What proved to open up the potential for a new narrative beyond/prior to the hegemonic shadow of Modernity is adding 
Frederick Cooper's criticism of how Modernity-as-trope contributes to confusion rather than clarity. ${ }^{43}$

Entirely appreciative of the nuances of Cooper's assertions that Modernity has overwhelmed our ability to talk about complex societies beyond all the artificial coherence and embedded contradictions Modernity creates, I started to highlight what proved in the different stories scattered in Ottoman documentation to be disjointed, multiple trajectories of human experience. I soon discovered that this stress on the possibility of repeating stories about various peoples that do not have to speak to a unified, mega-History (in our case today, that is Modernity), allows me to offer a critical rereading of what are on the surface, "non-European" themes of scholarship. In the process of such a rereading of events, it may be possible to actually find new significance, and thus new historical trajectories that do not have to necessarily serve the story of Modernity. As discussed throughout, local mobilizations will prove to be animating forces in their own right, compelling neighbors and global powers alike to reconfigure policies that often lead to adjustments and counter-moves, ultimately transforming everyone and everything involved in ways difficult-but not impossible-to translate today. ${ }^{44}$

This volume thus operates within a shared perspective of what is possible outside the epistemological hegemony of something called the "West" by engaging a new kind of story from within an often problematic comparative historiography of empire. One of the clear methodo[logical] problems I wish to avoid when engaging in such an exercise is falling into the trap of seeking "alternatives" to the targeted paradigm and suspected "truth" of a European Modernity, an effort that is doomed to reinforce the credibility of Modernity as an historic agent in the nineteenth century. ${ }^{45}$ The consequences of what Emmanuel Lévinas has called "the imperialism of theory," are the perpetuation of a form of knowledge that continues to juxtapose an ideal outsider/other with an ontological "West," an injustice to those who should be seen as legitimately operating at the radical exteriorities of our contemporary hegemonic narrative. ${ }^{46}$ Revisiting this seemingly outdated concern with ostracizing the logic of the ethico-political subordination of "non-western" agents/actors is especially relevant as I seek to realign the functional utility of studying the Ottoman Empire with larger ethical projects that aim to preserve a space of action for "the other" vis-à-vis Modernity. ${ }^{47}$

Of course, it has been argued that we can never fully escape from the language of ontology in the way offered by Lévinas. As Jacque Derrida suggests, the very act of writing in the voice of the idealized other in an attempt to resist the ontology of Modernity (and thus the pretensions of "the West") ultimately proves impossible because the operation of language requires at a most basic level that we integrate all the disparate voices, agents, and events we rescue from history. ${ }^{48}$ In other words, I run the risk of simply replacing Modernity with another totalizing concept. 


\section{Foundations of Modernity}

I am not so pessimistic, however, because it is not really my desire to write a parallel or "alternative" history to the "West" but to participate in denying the "West" to the extent that, at least for the nineteenth century, it is impossible to see a codified place we now call "Europe." 49 "Europe" in other words, does not exist in the time/space dynamics of my historical agents. Rather, it is individual moments involving a coalition of agents whose place in the moment is not determined by retrospection that informs the direction of analysis. ${ }^{50}$ The work of Derrida proves key to laying out what this means.

Despite his reputation, Derrida's work complements that of Lévinas, Althusser, and others by acknowledging that the ideological prism through which my (our) language about the past, present, and future is shaped, what is known as the "West," is not necessarily ubiquitous. Put differently, the "West" is not the dominant ideological and epistemological center of the world for most of those studied in this book, for most of the time. Peoples inhabiting the fringes of late nineteenth century empires mobilized their distinctive assets to address contingencies that lacked uniformity, thereby requiring us to remain within the local context while analyzing events. This decentering can, in theory, work to sabotage the underpinnings of Modernity-as-trope while writing about the nineteenth century.

In the end, rather than attacking the Hegelian idea of History, per se, by analyzing the implications of the general system from which History (in our case Modernity) operates, Derrida's often misrepresented "nihilism" complements the more concrete suggestions offered by Louis Althusser and Michel Foucault. ${ }^{51}$ Inspired by this, the following book adopts a particularly abstract presentation of various, dispersed, and disjointed events taking place in and around what may be called the Ottoman Empire. By avoiding what still reeks of Marxist determinism while situating disparate events taking place within the Ottoman domains in the larger narrative of Modernity, I suggest there is a way to avoid reifying the totalization of History so often underlying the scholarship about imperialism generally and the "Ottoman" experiences specifically. I do not, in the end, subscribe to the need to adopt a model of narration/presentation, especially as it includes the use of chronology that gives the reader the illusion of a linear series in order to ultimately satisfy our collective questions about the foundations of Modernity. ${ }^{52}$ There is something called a heterogeneous temporality that I believe complicates, if not entirely eludes, all theorization of modern history as a homogeneous diachrony. At the heart of this challenge that does not acknowledge the presence of the "West," I borrow heavily from Althusser's complicated argument about "decentered" and multiplied temporalities constituting historical moments that resist simple ideological framing. ${ }^{53}$

In laying out his argument, Althusser asserted that there is no uniform, total "ideological base time" to which all the many different temporalities happening at the "same time" can be linked. In such vast and culturally diverse territories like the Ottoman Empire, this is especially helpful 
because with an ordinary "single continuous reference time" it is not possible to write of many different events without resorting to composing a totalizing narrative. ${ }^{54}$

In other words, there were a plethora of experiences scattered throughout the Ottoman frontiers that neither reflect other events, happenings, and experiences taking place at the same time (often even within the same geographic space), nor permit absorption in the teleology of Modernity. Highlighting such experiences helps deny the inevitability of Modernity. Indeed, this "differential" account of history will help us to rethink a whole series of common notions about what has transpired in the past in relation to what we want it all to say about the present. As there can be no History of Modernity in general, only specific iterations of human action that service often contradictory purposes emerge as the primary engines of change. This in many ways returns people who never experienced Modernity back to a time when it was still not imaginable for such a totalized discursive tradition to impose the present inequalities asserted in binary form retroactively onto the past. ${ }^{55}$

It is possible, in other words, to use these multiple perspectives to write in different narrative forms that operate on entirely different plains of abstraction. History for Althusser, and for this book, is a function of the structure of the totality arising from a multiplicity of modes of production, those that could not transcend the specific context out of which they came. In other words, Modernity's "totality" in reality constitutes multiple "totalities" that constitute regular rupture and thus constant reorientation, reconstitution, and modified formalities. These modifications, geographically and temporally, spread across distinctive, often intersecting grids that are only retrospectively identified as the modes of production that reflect Modernity's assertion to total Truth and History. Modernity, in other words, belongs to the post-WWII world in which we, not those resurrected in this book, live. ${ }^{56}$

As this book progresses, I revisit these issues by highlighting in quite distinct locales and contexts the numerous and disparate actions of indigenous peoples. Foundations goes even further to suggest that some of these indigenous actions may have actually opened new spaces of action for external actors, who in time utilized these opportunities to assert what later became colonial regimes. That means, on some crucial intersection of time and space, what could have been entirely different inevitabilities interceded to at once lay the Foundations of our Modernity, actually closes the possibility for indigenous alternatives.

The many possible ways of accounting for the plethora of personal and collective ambitions and concerns that I suspect are at work in the Persian/Arab Gulf, Yemen, and the Western Balkans during the late Ottoman period can be accessed by innovative methods of representation already utilized in other genres of scholarship. For instance, it is possible to draw inspiration from the way social transformations are studied under the 


\section{Foundations of Modernity}

rubric of "creolization" or "border identity" in other literatures. ${ }^{57}$ These important interventions into understanding power and change in new ways may prove especially helpful in addressing a primary concern of mine here: contradicting what can be understood as the "epistemic coloniality" of power that reduces the study of the Ottoman and European world to an exercise of highlighting dichotomies enclosed by frontiers, both geographical and conceptual, as well as a particularistic understanding of "market forces" that exaggerate this binary construct of the world. ${ }^{58}$ Within the confines of this orientation are presumed polarities in otherwise complex, heterogeneous societies. Religion, along with race and ethnicity are thus seen as natural barriers, signifiers of primordial difference that distinguish pre-modern societies from those putatively conditioned by the Enlightenment, secularism, and Liberal values.

Instead of conceding to the kind of lexicon that reifies the use of differences, by integrating the dynamics of change in terms familiar to those theorizing borderlands, we can begin to interpret transformations prior to World War I as products of local engagement with imperial states (that is, more precisely, administrative extensions of certain configurations of capitalist power) that had considerable material resources but limited human capacities to control events fully. In this manner, it is possible to offer a reading of individual and collective possibilities that are tangible forces of history operating outside the confines laid out by certain models of analysis dependent on what can be called the meta-narrative of Modernity.

For this book, the biggest challenge present when exploring such intersections of human agency is addressing the difficulties in making intelligible the multiplicity of domestic knowledges that could be applied in any number of settings outside of History, that is Modernity. At the heart of the problem is respecting the context from within institutional, social, or political settings while practically using "events" to demonstrate that there are Foundations to Modernity that may suggest a different trajectory, if just explained differently. In other words, the mutations of contingency, reflective of indigenous actions, counter-actions, and reactions, as well as complications brought to the fore in domestic/internal debates within state bureaucracies, all complicate my task. Hopefully, the reward for unsealing some of these moments of intersection or "friction" along the borderlands of empire will be to render useless our Modernity as a historical totality for peoples deserving better. 


\title{
Bibliography
}

\section{ARCHIVAL SOURCES (LISTED BY COUNTRY)}

\author{
ALBANIA \\ Arkivi Qendror Shtetëror (Tiranë)-AQSH \\ AUSTRIA \\ Haus, Hauf und Staatsarchiv, (Vienna)-HHStA \\ FRANCE \\ Archives du Ministère des Affaires Étrangères (Paris)-AMAE \\ Centres des Archives diplomatiques de Nantes-AMAE Nantes \\ GERMANY \\ Politisches Archiv des Auswaertigen Amtes der Bundesrepublik Deutschland \\ -PAAA Bonn \\ ITALY \\ Archivio Storico del Ministero degli Affari Esteri (Rome)-ASAME \\ TURKEY \\ Başbakanlık Arşivi (Istanbul)-BBA \\ UNITED KINGDOM \\ Public Records Office (London)-PRO \\ Indian Office Record (London)-IOR \\ UNITED STATES OF AMERICA \\ United State of America (Washington DC) USNA RG
}

\section{PUBLISHED PRIMARY SOURCES}

I Documenti Diplomatici Italiani (Roma: 1974, 1985).

Documents Diplomatiques Français (Paris, 1884), volume 4.

Düstur (Istanbul)

Kosova Vilayet Salnamesi (1305/1888)

Makedonya'daki Osmanl Evraki, No: 29 (Ankara: T.C. Başbakanlık Devlet Arşivleri Genel Müdürlüğü Yayınları, 1996).

Salname-i Nezareti Maarifi Umumiye (Istanbul: Asır Matbaası, 1321).

Gümrükler Müdiriyeti Umumiyesi, Memaliki Osmaniyeden diyar-ı ecnebiyeye giden ve diyarıecnebiyeden Memalik-i Osmaniyeye gelen esyanin cins ve miktarı ve evvelki seneleri ile bilmuvazene tefavütünü havi istatistik cedvelleri (Istanbul: Matbaa-yı Osmaniye, 1304-1321).

Gümrükler Müdiriyeti Umumiyesi, Memaliki Şahaneye idhal olunan ve Diyarı ecenebiyeye ibrac olunan eşyanın istatistik, 1329 (Istanbul: Matbaa-y1 Osmaniye, 1330). 


\title{
244 Bibliography
}

\section{NEWSPAPERS/MAGAZINES}

\author{
Albania (Bucharest) \\ Asir (Istanbul) \\ Bashkimi (Alexandria) \\ Besa-Besë (Cairo) \\ Dersaadet Ticaret Odası Gazetesi (Istanbul) \\ Dituria (Sofia) \\ Drita (Istanbul) \\ Drita (Bucharest) \\ Kombi (Bucharest) \\ La Nazione Albanese (Catanzaro) \\ Le Phare du Bosphore (Istanbul) \\ Mülkiyye (Istanbul) \\ Pellazgu (Cairo) \\ Servet-i Fünun (Istanbul) \\ Shkreptima (Cairo) \\ Shqiptetaret n'Egjypte (Cairo) \\ Toska (Cairo) \\ Vatra (Minya al-Qamh) \\ Vetëtima (Bucharest) \\ Zghimi (Cairo)
}

\section{UNPUBLISHED SOURCES: DISSERTATIONS AND THESIS}

Akarlı, Engin D. The Problems of External Pressures, Power Struggles, and Budgetary Deficits in Ottoman Politics under Abdülhamid II (1876-1909): Origins and Solutions (PhD Dissertation, Princeton University, 1976).

McKnight, James L. "Admiral Ushakov and the Ionian Republic: The Genesis of Russia's First Balkan Satellite," (PhD Dissertation: University of WisconsinMadison, 1965).

Quataert, Donald. Ottoman Reform and Agriculture in Anatolia (PhD Dissertation, UCLA, 1973).

Sezer, Hamiyet. “Tepedelenli Ali Paşa Isyanı,” (PhD Dissertation: Ankara University, 1995).

Themopoulou, Emilia. Salonique, 1800-1875: Conjoncture Economique et Mouvement Commercial (PhD Thesis: Paris, Université de Paris I, 1994).

\section{PUBLISHED NON-PRIMARY SOURCES}

al 'Abdali, Ahmad Fadl ibn 'Ali Muhsin. Hadiyat al-Zaman fi Akhbar Muluk Lahj wa Adan (Cairo: Salafiyah, 1932).

Abernethy, David. The Dynamics of Global Dominance: European Overseas Empires, 1415-1980 (New Haven: Yale University Press, 2000).

Abir, Mordechai. Ethiopia: Era of the Princes (New York: Praeger Publishers, 1968).

Abou-El-Haj, Rifa'at. Formation of the Modern State: The Ottoman Empire Sixteenth to Eighteenth Centuries (New York: Syracuse University Press, 2001). Adanır, Fikret. Die Makedonische Frage (Wien: Franz Steiner Verlag, 1979). 
Adanır, Fikret. "Heiduckentum und Osmanische Herrschaft," Südost-Forschungen 41 (1982): 43-116.

Adanır, Fikrit. "The Macedonian Question: The Socio-Economic Reality and Problems of its Historiographic Interpretation," International Journal of Turkish Studies 3.1 (1984-1985): 43-64.

Afary, Janet and Kevin B. Anderson. Foucault and the Iranian Revolution: Gender and the Seductions of Islamism (Chicago: University of Chicago Press, 2005).

Akarl, Engin D. The Long Peace: Ottoman Lebanon, 1861-1920 (Berkeley: University of California Press, 1993).

Akarlı, Engin. "The Tangled Ends of an Empire: Ottoman Encounters with the West and Problems of Westernization-an Overview," Comparative Studies of South Asia, Africa and the Middle East 26.3 (2006): 353-366.

Akgündüz, Ahmet. Mukayeseli Islam ve Osmanlı Hukuku Külliryatı (Diyarbakır: Dicle Universitesi Hukuk Fakultesi Yayınları, 1986).

Aksan, Virginia. Ottoman Wars 1700-1870: An Empire Besieged (Harlow: Longman, 2007).

Aktan, R. "The Burden of Taxation on the Peasants," in Charles Issawi (ed.), The Economic History of Turkey, 1800-1914 (Chicago: University of Chicago Press, 1980): 109-113.

Althusser, Louis. For Marx. Trans. Ben Brewster (London: Penguis Press, 1969).

Althusser, Louis. Lenin and Philosophy and Other Essays. Trans. Ben Brewster (New York: Monthly Review Press, 1971).

Althusser, Louis and Étienne Balibar, Reading Capital. Trans. Ben Brewster (London: New Left Books, 1970).

Anastasopoulos, Antonios. "Lighting the Flame of Disorder: Ayan Infighting and State Intervention in Ottoman Karaferye, 1758-1759," International Journal of Turkish Studies 8 (2002): 73-88.

Anderson, Benedict. Imagined Communities: Reflections on the Origin and Spread of Nationalism (New York: Verso, 1983).

Anderson, Perry. Lineages of the Absolutist State (London: Verso, 1974).

Anscombe, Frederick F. The Ottoman Gulf: The Creation of Kuwait, Saudi Arabia, and Qatar (New York: Columbia University Press, 1997).

Anscombe, Frederick F. "Albanians and 'Mountain Bandits," in Frederick Anscombe (ed.), The Ottoman Balkans, 1750-1830 (Princeton, NJ: Markus Wiener Publishers, 2006): 87-114.

Anscombe, Frederick. "Islam and the Age of Ottoman Reform," Past and Present 208 (August 2010): 159-189.

Antoljak, Stjepan. "Prilog historijatu borbe Albanaca za svoj alfabet," Gjurmime Albanologjike II.1 (1969): 23-57.

Appadurai, Arjun. Modernity at Large: Cultural Dimensions of Globalization (Minneapolis, : University of Minnesota Press, 1996).

Aral, Berdal. "The Idea of Human Rights as Perceived in the Ottoman Empire," Human Rights Quarterly 26.2 (2004): 454-482.

Asad, Talal. "Conscripts of Western Civilization," in Christine Gailey (ed.), Dialectical Anthropology: Essays in Honor of Stanley Diamond, Vol. 1, Civilization in Crisis (Gainesville: University of Florida Press, 1992): 333-351.

Asad, Talal. Geneologies of Religion: Discipline and Reasons of Power in Christianity and Islam (Baltimore: Johns Hopkins University Press, 1993).

Asad, Talal, "Ethnographic Representation, Statistics and Modern Power," in Brian Keith Axel (ed.), From the Margins: Historical Anthropology and its Futures (Durham, NC: Duke University Press, 2002): 66-91.

Asad, Talal. Formations of the Secular: Christianity, Islam, Modernity (Palo Alto: Stanford University Press, 2003). 


\section{Bibliography}

Aslanian, Sebouh David. From the Indian Ocean to the Mediterranean: The Global Trade Networks of Armenian Merchants from New Julfa (Berkeley: University of California Press, 2011).

Austen, Ralph. "The Islamic Red Sea Slave Trade: An Effort at Quantification," in Robert Hess (ed.), Proceedings of the Fifth International Conference on Ethiopian Studies (Chicago: University of Illinois Chicago Circle Press, 1979): 461-465.

Autheman, André. La Banque impérial ottomane (Paris: Comité pour l'histoire économique et financière de la France, 1996).

Aybar, Celal. Osmanl Imparatorluğunun Ticaret Muvazensesi, 1878-1913 (Ankara: Devlet Istatistik Enstitüsü, 1939).

Bailey, Frank E. “The Economics of British Foreign Policy, 1825-50," The Journal of Modern History 12.4 (Dec. 1940): 449-484.

Bairoch, Paul. "European Trade Policy, 1815-1914," in Peter Mathias and Sideny Pollard (eds.), The Cambridge Economic History of Europe: The Industrial Economies: The Development of Economic and Social Policies, V, VII (Cambridge: Cambridge University Press, 1989): 1-160.

Bardey, Alfred. Barr-Adjam, souvenirs d'Afrique Orientale, 1880-1887 (Paris: Centre national de la recherche scientifique, 1981).

Barkey, Karen. Empire of Difference: The Ottomans in Comparative Perspective (New York: Cambridge University Press 2008).

Bayly, C.A. Imperial Meridian: The British Empire and the World, 1780-1830 (London: Longman, 1989).

Belin, Marcel. "Étude sur la propriété foncière en pays Musulmans, et spécialement en Turquie," Journal Asiatique (Avril-Mai, 1862): 291-358.

Benhabib, Seyla. "Feminism and the Question of Postmodernism," in Seyla Benhabib, Judith Butler, Drucilla Cornell, and Nancy Fraser (eds.), Feminist Contentions: A Philosophical Exchange (New York Routledge, 1994): 17-34.

Bentley, Jerry H. "Myths, Wagers, and Some Moral Implications of World History," Journal of World History 16.1 (2005): 52-82.

Benton, Lauren. Law and Colonial Cultures: Legal Regimes in World History, 1400-1900 (Cambridge: Cambridge University Press, 2002).

Berkes, Niyazi. The Development of Secularism in Turkey (London: Hurst, 1998).

Beverley, John. Subalternity and Representation: Arguments in Cultural Theory (Durham, NC: Duke University Press, 1999).

Beydilli, Kemal. "II. Abdülhamid Devrinde Makedonya Meselesine Dair,” Osmanl Araştırmaları IX (1989), 94-96.

Bhabha, Homi K. "The Third Space: Interview with Homi Bhabha," in J. Rutherford (ed.), Identity, Community, Culture, Difference (London: Lawrence and Wishart 1990): 207-221.

Biliotti, Antanio. La Banque Imperiale Ottomane (Paris: Jouve et cie, 1909).

Bingöl, Sedat. Tanzimat Devrinde Osmanlida Yargi Reformu: Nizamiyye Mahkemeleri'nin Kuruluşu ve Işleyişi, 1840-1876 (Eskişehir: Anadolu Üniversitesi Yayınları 2004).

Biolsi, Thomas. "The Birth of the Reservation: Making the Modern Individual among the Lakota," American Ethnologist 22.1 (Feb. 1995): 28-53.

Birdal, Murat. The Political Economy of Ottoman Public Debt: Insolvency and European Financial Control in the Late Nineteenth Century (London: I.B. Tauris, 2010).

Blaisdell, Donald C. European Financial Control in the Ottoman Empire (New York: Columbia University Press, 1929).

Blaut, James M. The Colonizer's Model of the World: Geographical Diffusionism and Eurocentric History (New York: Guilford Press, 1993). 
Blumi, Isa. "Teaching Loyalty in the Late Ottoman Balkans: Educational Reform in the Vilayets of Manastir and Yanya, 1878-1912," Comparative Studies of South Asia, Africa and the Middle East 21 (October, 2001): 15-23.

Blumi, Isa. Rethinking the Late Ottoman Empire: A Comparative Social and Political History of Albania and Yemen, 1878-1918 (Istanbul: Isis Press, 2003).

Blumi, Isa. "Contesting the Edges of the Ottoman Empire: Rethinking Ethnic and Sectarian Boundaries in the Malësore, 1878-1912," IJMES 35.2 (May 2003): 237-256.

Blumi, Isa. "Capitulations in the Late Ottoman Empire: The shifting parameters of Russian and Austrian interests in Ottoman Albania, 1878-1912," Oriente Moderno 83.3 (2003): 635-647.

Blumi, Isa. "Reconsidering the Social History of Ottoman Yemen, 1872-1918" in Vitalis and al-Rasheed (eds.) Counter Narratives: History, Contemporary Society and Politics in Saudi Arabia and Yemen (New York: Palgrave, 2004): 103-119.

Blumi, Isa. "Austrian Strategies in Ottoman Albania: The School and the Fall of Sectarian Politics," in Martin Scheutz et al. (eds.), Das Osmanische Reich und die Habsburgermonarchie in der Neuzeit (Wien: Oldenbourg: 2005): 595-611.

Blumi, Isa. "The Evolution of Red Sea Trade in the $19^{\text {th }}$ Century Ottoman Yemen," Journal of Turkish Studies Special Issue: In Memoriam Şinasi Tekin, 31.1 (2007): 157-175.

Blumi, Isa. "The Frontier as a Measure of Imperial Power: Local Limits to Empire in Yemen, 1872 to 1914," in AGC Peacock (ed.), Ottoman Frontiers: Political History of Territorial Limits (Oxford University Press, 2009): 289-304.

Blumi, Isa. "Illicit Trade and the Emergence of Albania and Yemen," in I. William Zartman (ed.), Understanding Life in the Borderlands: Boundaries in Depth and in Motion (Athens: University of Georgia Press, 2010): 73-100.

Blumi, Isa. "Adding New Scales of History to the Eastern Mediterranean: Illicit Trade and the Albanian," in Meltem Toksoz and Biray Kirli (eds.), Cities of the Mediterranean: From the Ottomans to the Present Day (London: I.B.Tauris, 2010): 116-138.

Blumi, Isa. Chaos in Yemen: Societal Collapse and the New Authoritarianism (London: Routledge, 2010).

Blumi, Isa. "Entangled Trajectories: The Interweaving Interests of the Local and the Evolution of Modern Imperialism in the Balkans," Balkanistica 23 (2011): 75-108.

Blumi, Isa. Reinstating the Ottomans: Alternative Balkan Modernities, 18001912 (New York: Palgrave Macmillan, 2011).

Boca, Angelo del. Gli Italiani in Africa Orientale: Dall'Unita alla Marcia su Roma (Roma: Arnoldo Mondadori, 1992).

Bohme, Helmut. "Big-Business Pressure Groups and Bismark's Turn to Protectionism, 1873-1879," The Historical Journal 10.2 (1967): 218-236.

Bonacich, Edna. "A Theory of Middleman Minorities," American Sociological Review 38 (1973): 583-594.

Borchard, Edwin. State Insolvency and Foreign Bondholders: General Principles (New Haven: Yale University Press, 1951).

Borer, Alain. Rimbaud en Abyssinie (Paris: Seuil, 2004).

Bottici, Chiara. Men and States: Rethinking the Domestic Analogy in a Global Age (New York: Palgrave Macmillan 2009).

Bouquet, Olivier. Les pachas du sultan: Essai sur les agents supérieurs de l'État ottoman (1839-1909) (Paris: Peeters, 2007).

Boyar, Ebru. Ottomans, Turks and the Balkans: Empire Lost, Relations Altered (London: Tauris Academic Studies, 2007). 


\section{Bibliography}

Boyer, John W. Political Radicalism in Late Imperial Vienna: Origins of the Christian Social Movement, 1848-1897 (University of Chicago Press, 1995).

Bozkurt, Gülnihal. Gayrimüslim Osmanlı Vatandaşlarının Hukuki Durumu (1839-1914) (Ankara: Türk Tarih Kurumu, 1996).

Brah, Avtar. Cartographies of Diaspora: Contesting Identities (New York: Routledge, 1996).

Bratter, Herbert M. Silver Market Dictionary (New York: Commodity Exchange, Inc., 1933).

Brubaker, Rogers. Nationalism Reframed (New York: Cambridge University Press, 1996).

Brubraker, Rogers. "Ethnicity without Groups," Archives européenes de sociologie XLIII.2 (2002): 163-189.

Brubaker, Rogers. "The 'diaspora' Diaspora," Ethnic and Racial Studies 28.1 (Jan.2005): 1-19.

Burbank, Jane and Frederick Cooper, Empires in World History: Power and the Politics of Difference (Princeon, NJ: Princeton University Press, 2010).

Bury, G. Wyman. The Land of Uz (London: Macmillan and Col. Ltd., 1911).

Bushati, Hamdi. Shkodra dhe Motet: Traditë Ngjarje Njerëz, 2 vols. (Shkodër: Idromeno, 1998).

Butler, Judith. "Restaging the Universal: Hegemony and the Limits of Formalism," in Judith Butler, Ernesto Laclau (eds.) Contingency, Hegemony, Universality: Contemporary Dialogues on the Left (London: Verso, 2000): 11-43.

Campbell, David, Morton Schoolman, and Thomas L. Dumm, The New Pluralism: William Connolly and the Contemporary Global Condition (Durham, NC: Duke University Press, 2008).

Carter, Paul. The Road to Botany Bay: Exploration in Landscape and History (Chicago: University of Chicago Press, 1987).

Cassanelli, Lee. "Social Construction on the Somali Frontier: Bantu Former Slave Communities in the Nineteenth Century," in Ivan Kopytoff (ed.), The African Frontier: The Reproduction of Traditional African Societies (Bloomington: Indiana University Press, 1989): 216-238.

Ciasca, Raffaele. Storia coloniale dell'Italia contemporanea da Assab all'Impero (Milano: Ulrico Hoepli, 1940).

Clancy-Smith, Julia. Mediterraneans: North Africa and Europe in an Age of Migration, c. 1800-1900 (Berkeley: University of California Press, 2010).

Clarence-Smith, William G. The Economics of the Indian Ocean Slave Trade in the Nineteenth Century (London: Routledge, 1989).

Clay, Christopher. Gold for the Sultan: Western Bankers and Ottoman Finance 1856-1881: A Contribution to Ottoman and to International Financial History (London: I.B. Tauris, 2000).

Clayer, Nathalie. L'Albanie, pays des derviches (Berlin: Otto Harrassowitz, 1990).

Clayer, Nathalie. "The Albanian Students of the Mekteb-i Mulkiye: Social Networks and Trends of Thought", in Elisabeth Ozdalga (ed.), Late Ottoman Society: The Intellectual Legacy (London: Routledge/Curzon Press, 2005): 289-339.

Clayer, Nathalie. Aux origines du nationalisme albanais: La naissance d'une nation majoritairement musulmane en Europe (Paris: Karthala, 2006).

Clifford, James. “Diasporas,” Cultural Anthropology 9.3 (1994): 302-338.

Codignola, Arturo. Rubattino (Bologna: Cappelli, 1938).

Connolly, William E. The Ethos of Pluralization (Minneapolis: University of Minnesota Press, 1995).

Connolly, William E. Identity|Difference: Democratic Negotiations of Political Paradox (Minneapolis: University of Minnesota Press, 2002). 
Connolly, William E. "Europe: A Minor Tradition,” in Charles Hirschkind and David Scott (eds.), Powers of the Secular Modern: Talal Asad and his Interlocutors (Palo Alto: Stanford University Press, 2006): 75-92.

Cooper, Frederick. "Empire Multiplied. A Review Essay," Comparative Study of Society and History 46.2 (2004): 247-272.

Cooper, Frederick. Colonialism in Question: Theory, Knowledge, History (Berkeley: University of California Press, 2005).

Cooper, Frederick and Ann Lauria Stoler (eds.) Tensions of Empire: Colonial Cultures in A Bourgeois World (Berkeley: University of California Press, 1989).

Coronil, Fernando. The Magical State: Nature, Money, and Modernity in Venezuela (Chicago: University of Chicago Press, 1997).

Corrigan, Philip and Derek Sayer, The Great Arch: English State Formation as Cultural Revolution (Oxford: Blackwell, 1991).

Cuno, Kenneth M. The Pasha's Peasants: Land, Society, and Economy in Lower Egypt, 1740-1858 (Cambridge: Cambridge University Press, 1993).

Daguenet, Roger. Aux origins de l'implantation française en mer Rouge. Vie et mort de Henri Lambert (Paris: L'Harmattan, 1992).

Dakin, Douglas. The Greek Struggle in Macedonia, 1897-1913 (Thessaloniki: Institute for Balkan Studies, 1993).

Dale, Stephen F. The Muslim Empires of the Ottomans, Safavids, and Mughals (Cambridge: Cambridge University Press, 2010).

Da'ud, Mahmud 'Ali. 'Russia and the Persian Gulf: Study in Pre-World War I Diplomacy,' Bulletin of the College of Arts and Sciences, University of Iraq III (June 1958): 118-132.

Darwin, John. "Imperialism and the Victorians: The Dynamics of Territorial Expansion," English Historical Review 112 (1997): 614-642.

Davidson, Roderic H. Reform in the Ottoman Empire, 1856-1876 (Princeton, NJ: Princeton University Press, 1963).

Davis, Mike. Late Victorian Holocausts: El Niño Famines and the Making of the Third World (London: Verso, 2002).

Derrida, Jacque. Of Grammatology. Trans. Gayatri Chakravorty Spivak (Baltimore, MD: The Johns Hopkins University Press, 1976).

Derrida, Jacque. Writing and Difference. Trans. Alan Bass (London: Routledge \& Kegan Paul, 1978).

Derrida, Jacques. Positions. Trans. Alan Bass. (London: Athlone Press, 1981).

Deringil, Selim. "'They Live in a State of Nomadism and Savagery': The Late Ottoman Empire and the Post-Colonial Debate," CSSH 45.3 (2003): 311-342.

Dërmaku, Ismet. Nikolla N. Naço-Korça (1843-1913): Apostuli i Shqiptarizmit (Prishtinë: NP, 2000).

Dërmaku, Ismet. Kuvendi i Lidhjes Shqiptare të Pejës 'Besa Besë’ 1899 (Prishtinë: NP, 1997).

Devereux, Robert. The First Ottoman Constitutional Period: A Study of the Midhat Constitution and Parliament (Baltimore: Johns Hopkins University Press, 1963).

Dirks, Nicholas B. The Scandal of Empire: India and the Creation of Imperial Britain (Cambridge, MA: Belknap Press, 2008).

Doçi, Pal Pjetër. Imzot Prend Doci, Abati i Mirditës: Jeta dhe Vepra (Tiranë: Naim Frashëri, 1997).

Dodani, Visar. Memoret e Mija (Constanţa, 1930).

Donnan, Hastings and Thomas M. Wilson (eds.) Border Approaches: Anthropological Perspectives on Frontiers (Washington DC: University Press of America, 1994).

Dragostinova, Theodora. "Navigating Nationality in the Emigration of Minorities between Bulgaria and Greece, 1919-1941," East European Politics and Societies 23.2 (Spring, 2009): 185-212. 


\section{Bibliography}

Drury, Ian. The Russo-Turkish War, 1877 (London: Osprey, 1994).

Dubois, Colette. "Changements dans la continuité ou dans la rupture. Les implantations portuaires égyptiennes et européennes en mer Rouge, dans la deuxième moitié du XIXe siècle," in Abdeljelil Temini (ed.), Les Villes Arabes, la Démographie Historique et la Mer Rouge à l'Époque Ottomane (Zaghouan: Ceromdi, 1994): 43-65.

Duce, Alessandro. L'Albania nei rapporti italo-austriaci, 1897-1913 (Milano: A. Giuffrè, 1983).

Dufoix, Stéphanie. Diasporas (Berkeley: University of California Press, 2008).

Dundas, F.G. "Expedition up the Jub River through Somali-land, East Africa." The Geographical Journal 1 (1893): 209-223.

Edney, Matthew. Mapping an Empire: The Geographical Construction of British India, 1765-1843 (Chicago: University of Chicago Press, 1997).

Eldem, Edhem, Daniel Goffman, and Bruce Masters, The Ottoman City between East and West: Aleppo, Izmir, and Istanbul (Cambridge: Cambridge University Press, 2005).

Eldem, Vedat. Osmanlı Imparatorluğunun Iktisadi Şartları Hakkinda bir Tetkik (Istanbul: Iș Bankası Yayınları, 1970).

Eren, Ahmet C. Türkiye'de Göçve Göçmen Meseleleri (Istanbul: Nurgök, 1966).

Erol, Mine. Osmanlı Imparatorluğunda Kă̆ıt Para (Kaime) (Ankara: Türk Tarih Kurumu Basımevi, 1970).

Evans, R.J.W. and Hartmut Pogge von Strandmann (eds.), The Revolutions in Europe, 1848-1849: From Reform to Reaction (Oxford: Oxford University Press, 2002).

Fahmy, Khaled. All the Pashas Men: Mehmed Ali, His Army and the Making of Modern Egypt (Cairo: American University of Cairo Press, 2002).

Farah, Caesar E. The Sultan's Yemen: Nineteenth-Century Challenges to Ottoman Rule (London: I.B. Tauris, 2002).

Fattah, Hala. The Politics of Regional Trade in Iraq, Arabia and the Gulf (Albany: State University of New York Press, 1997).

Fawaz, Leila. Merchants and Migrants in Nineteenth Century Beirut (Cambridge: Cambridge University Press, 1983).

Ferguson, James. Expectations of Modernity: Myths and Meanings of Urban Life on the Zambian Copperbelt (Berkeley: University of California Press, 1999).

Ferguson, Niall. Empire: The Rise and Demise of the British World Order and the Lessons for Global Power (London: Allen Lane, 2002).

Ferguson, Niall. The Ascent of Money: A Financial History of the World (New York: Penguin, 2008).

Ferid, Hasan. Nakid ve Itibar-ı Mali, 4 vols. (Istanbul: Hukuk Mutbaası, 19141918).

Findley, Carter V. Bureaucratic Reform in the Ottoman Empire: The Sublime Porte, 1789-1922 (Princeton, NJ: Princeton University Press, 1980).

Findley, Carter V. "The Tanzimat," in Reşat Kasaba (ed.), The Cambridge History of Turkey, Vol. 4, Turkey in the Modern World (Cambridge: Cambridge University Press, 2008), 11-37.

Finkel, Caroline. Osman's Dream: The History of the Ottoman Empire (New York: Basic Books, 2007).

Firaunit Kul'e [J. Vruho], "Shqiptaretaret n'Egjypte”, Kalendari Kobiar (Sofia) 1908, 49-58.

Fleming, Katherine. The Muslim Bonaparte: Diplomacy and Orientalism in Ali Pasha's Greece (Princeton, NJ: Princeton University Press, 1999).

Fletcher, Max E. “The Suez Canal and World Shipping, 1869-1914," The Journal of Economic History 18 (1958): 556-573.

Fortna, Benjamin C. Imperial Classroom: Islam, the State, and Education in the Late Ottoman Empire (New York: Oxford University Press, 2002). 
Foucault, Michel. The Order of Things: An Anthropology of the Human Sciences (New York: Pantheon Books, 1971).

Foucault, Michel. The Archaeology of Knowledge \& the Discourse on Language, trans. A.M. Sheridan Smith (London: Tavistock, 1972).

Foucault, Michel. The History of Sexuality. Volume I: An Introduction (New York: Vintage, 1978).

Foucault, Michel. "Questions of Geography," in Colin Gordon (ed.), Power/ Knowledge: Selected Interviews and Other Writings, 1972-1977 (New York: Pantheon Books, 1980): 63-77.

Foucault, Michel. "The Subject and Power," in Hubert L. Dreyfus and Paul Rabinow (eds.), Michel Foucault: Beyond Structuralism and Hermeneutics (Chicago: Chicago University Press, 1983): 208-226.

Foucault, Michel. Politics, Philosophy, Culture: Interviews and Other Writings 1977-1984, edited by Lawrence D. Kritzman, trans. Alan Sheridan, (New York: Routledge, 1988).

Frank, Andre Gunder. ReOrient: Global Economy in the Asian Age (Berkeley: University of California Press, 1998).

Fraser, Nancy and Axel Honneth, Redistribution or Recognition? A Political-Philosophical Exchange (London: Verso, 2003).

Frashëri, Kristo. Lidhja Shqiptarë e Prizrenit, 1878-1881 (Tiranë: TOENA, 1997).

Frashëri, Sami. Shqipëria ç’ka qenë, ç’është e ç’do bëhetë (Bukuresht: Shoqëria Dituria, 1899).

Fuccaro, Nelida. Histories of City and State in the Persian Gulf: Manama since 1800 (Cambridge: Cambridge University Press, 2009).

Fuss, Diana. Essentially Speaking (New York: Routledge, 1989).

Gates, Jr., Henry Louis. "Critical Fanonism," Critical Inquiry 17.3 (Spring, 1991): 457-470.

Gavin, R.J. Aden under British Rule, 1839-1967 (London: C. Hurst \& Company, 1975).

Gavrilis, George. “The Greek-Ottoman Boundary as Institution, Locality, and Process, 1832-1882," American Behavioral Scientist 51.10 (June 2008): $1516-1537$.

Gavrilis, George. The Dynamics of Interstate Boundaries (Cambridge: Cambridge University Press, 2010).

Gawrych, George. The Crescent and the Eagle: Ottoman Rule, Islam and the Albanians, 1874-1913 (London: I.B. Tauris, 2006).

Genç, Mehmet. Osmanlı Imparatorluğunda Devlet ve Ekonomi (Istanbul: Ötüken Neşriyat, 2000).

Ghanim, Tariq Abd al 'Ati. Siyasah Misri fi al-Bahr al-Ahmar fi al-Nisf al-awal min al-Qarn al-Tisa' 'ashra, 1811-1848 (Cairo: al-hiya'ah al-Misriyya al'umma lil-kitab, 1999).

Gingeras, Ryan. "Between the Cracks: Macedonia and the 'Mental Map' of Europe," Canadian Slavonic Papers 50.3-4 (Sept-Dec. 2008): 341-358.

Gingeras, Ryan. Sorrowful Shores: Violence, Ethnicity, and the End of the Ottoman Empire, 1912-1923 (New York: Oxford University Press, 2009).

Gingeras, Ryan. "Last Rites for a 'Pure Bandit': Clandestine Service, Historiography and the Origins of the Turkish 'Deep State," Past \& Present 206.1 (2010): 151-174.

Gladstone, William E. Bulgarian Horrors and the Question of the East (London: John Murray, 1876).

Gounaris, Basil C. "Emigration from Macedonia in the Early $20^{\text {th }}$ Century," Journal of Modern Greek Studies 7 (1989): 133-153.

Gounaris, Basil C. Steam over Macedonia, 1870-1912: Socio-economic Change and the Railway Factor (New York: East European Monographs, 1993). 


\section{Bibliography}

Gounaris, Basil C. "Social Cleavages and National 'Awakening' in Ottoman Macedonia,” Eastern European Quarterly 24.4 (January 1996), 409-426.

Göçek, Fatma Müge. Rise of the Bourgeoisie, Demise of Empire. Ottoman Westernization and Social Change, (Oxford: Oxford University Press, 1996).

Göçek, Fatma Müge. "Ethnic segmentation, western education, and political outcomes: nineteenth-century Ottoman Society," Poetics Today 14.3 (Autumn, 1993): 507-538.

Gran, Peter. Islamic Roots of Capitalism: Egypt, 1760-1840 (Syracuse, NY: Syracuse University Press, 1998).

Gran, Peter. Beyond Eurocentrism: A New View of Modern World History (Syracuse, NY: Syracuse University Press, 1996).

Gregory, Derek. Geographical Imaginations (Oxford: Blackwell, 1994).

Guha, Ranajit. History at the Limit of World History (New York: Columbia University Press, 2002).

Güran, Tevfik. Osmanlı Devleti’nin Ilk Istatistik Yıllı̆̆ı, 1897 (Ankara: T.C. Başbakanlık Devlet Istatistik Enstitüsü, 1997).

Güran, Tevfik. 19 Yüzyil Osmanlı Tarımı Üzerine Araştırmalar (Istanbul: Eren Yayinçılık, 1998).

Haj, Samira. Reconfiguring Islamic Tradition: Reform, Rationality, and Modernity (Palo Alto: Stanford University Press, 2010).

Hall, Stuart. "Race, Articulation, and Societies Structured in Dominance," in UNESCO (ed.), Sociological Theories: Race and Colonialism (Paris: UNESCO, 1980).

Hall, Stuart. "Signification, Representation, Ideology: Althusser and the PostStructuralist Debates," Critical Studies in Mass Communication 2.2 (June 1985): 91-114.

Hall, Stuart. "Cultural Identity and Diaspora," in Padmini Mongia (ed.), Contemporary Postcolonial Theory: A Reader (London: Arnold, 1996): 110-121.

Hanioğlu, Şükrü. The Young Turks in Opposition (New York: Oxford University Press, 1995).

Hanioğlu, M. Şükrü. Preparation for a Revolution: The Young Turks, 1902-1908 (Oxford: Oxford University Press, 2001).

Hanioğlu, M. Şükrü. A Brief History of the Late Ottoman Empire (Princeton, NJ: Princeton University Press, 2008).

Hans, Jürgen. Marie-Teresien Taler (Leiden: Brill, 1961).

Hanssen, Jens. "Practices of Integration: Center-periphery Relations in the Ottoman Empire," in Jens Hanssen, Thomas Philipp, and Stefan Weber (eds) The Empire in the City: Arab Provincial Capitals in the Late Ottoman Empire (Würzburg: Ergon, 2002): 49-74.

Hanssen, Jens. Fin de Siècle Beirut: The Making of an Ottoman Provincial Capital (Oxford: Oxford University Press, 2005).

Hanssen, Jens. "'Malhamé-Malfamé': Levantine Elites and Trans-imperial Networks on the Eve of the Young Turk Revolution," IJMES 43.1 (2011).

Harely, C.K. "Transportation, the World Wheat Trade and the Kuznets Cycle, 1850-1913," Explorations in Economic History 17 (1980): 218-250.

Harlaftis, Gelina. "Mapping the Greek Maritime Diaspora from the Early Eighteenth to the Late Twentieth Centuries," in Ina B. McCabe, Gelina Harlaftis, and Ioanna P. Minoglou (eds.), Diaspora Entrepreneurial Networks: Four Centuries of History (Oxford: Berg, 2005): 147-173.

Hasluck, Margaret. The Unwritten Law in Albania (Cambridge: Cambridge University Press, 1954).

Hertselt, Edward. The Map of Europe by Treaty (1814-1891) (London: Butterworth, 1891).

al-Hibshi, 'Abdallah Muhammad. Masadir al-fikr al-'arabi al-islami fil-Yaman, (San'a': Markaz al-Dirasat al Yamaniyya, n.d.). 
al-Hibshi, 'Abdullah b. Muhammad. Hawliyyat yamaniyyah min sanah 1225 h. ila sanah 1316 h. (San'a': Wizarat al-I'lam wa-1-Thaqafah, 1980).

Hirschkind, Charles. The Ethical Soundscape: Cassette Sermons and Islamic Counterpublics (New York: Columbia University Press 2006).

Hirschon, Renee (ed.) Crossing the Aegean: An Appraisal of the 1923 Compulsory Population Exchange between Greece and Turkey (New York: Berghahn Books, 2003).

Hobsbawm, Eric. The Age of Capital, 1848-1975 (New York: Mentor, 1979).

Hobsbawm, Eric. The Age of Empire 1875-1914 (New York: Pantheon, 1987).

Holland, Trevenen J. and Henry M. Hozier, Record of the Expedition to Abyssinia, 2 vols., (London: Topographical and Statistical Department, War Office, 1870).

Hoxha, Teuta (ed.), Ismail Qemali: Përmbledhje Dokumentesh, 1888-1919 (Tiranë: 8 Nëntori, 1985).

Hroch, Miroslav. Social Preconditions of National Revival in Europe: A Comparative Analysis of the Social Composition of Patriotic Groups among the Smaller European Nations (Cambridge: Cambridge University Press, 1985).

Hubka, Gustav. Die Österreichisch-Ungarische Offiziermission in Makedonien: 1903-1909 (Wien: F. Tempsky, 1910).

Hugill, Peter J. World Trade since 1431: Geography, Technology and Capitalism (Baltimore: Johns Hopkins University Press, 1993).

Hurewitz, J.C. Diplomacy in the Near and Middle East: A Documentary Record 2 vols. (Princeton, NJ: Princeton University Press, 1956).

Ibrahim Manzour Efendi, Mémoires sur la Grèce et l'Albanie pendant le gouvernement d'Ali-Pacha (Paris: P. Ledoux, 1827).

Içduygu, Ahmet and B. Ali Soner, "Turkish Minority Rights Regime: Between Difference and Equalty," Middle Eastern Studies 42.3 (May 2006): 447-468.

Ipek, Nedim. Rumeli'den Anadolu'ya Türk Göçleri (Ankara: Türk Tarih Kurumu Basımevi, 1994).

Inalcık, Halil, Suraiya Faroqhi, Bruce McGowan, and Donald Quataert, An Economic and Social History of the Ottoman Empire (Cambridge: Cambridge University Press, 1997).

Issawi, Charles. The Economic History of Turkey (Chicago: University of Chicago Press, 1980).

Issawi, Charles. An Economic History of the Middle East and North Africa (New York: Columbia University Press, 1982).

Islami, Nehat. "Gjurmevë të Mehmet Ali Pashës dhe ushtrisë së tij,” Rilindja 28.7 (17 August 1977): 12.

Islamoğlu, Huri. "Property as a Contested Comain: A Reevaluation of the Ottoman Land Code of 1858," in Roger Owen (ed.), New Perspectives on Property and Land in the Middle East (Cambridge, MA: Harvard University Press, 2001): 3-61.

Jacob, M.C. and Ira Katznelson, "Agendas for Radical History," Radical History Review 36 (September 1986): 26-47.

JanMohamed, Abdul. "The Economy of Manichean Allegory: The Function of Racial Differnce in Colonialist Literature," Critical Inquiry 12 (1985): 59-87.

Jelavich, Barbara. History of the Balkans: Twentieth Century (Cambridge: Cambridge University Press, 1983).

Jelavich, Barbara. Russia's Balkan Entanglements, 1806-1914 (Cambridge: Cambridge University Press, 1991).

Jokl, Norbert. Linguistisch-kulturhistorische Untersuchungen aus dem Bereiche des Albanischen (Berlin, W. de Gruyter, 1923).

Judson, Pieter M. Exclusive Revolutionaries: Liberal Politics, Social Experience, and National Identity in the Austrian Empire, 1848-1914 (Ann Arbor: University of Michigan Press, 1996). 


\section{Bibliography}

Jwadieh, Albertine. "Aspects of Land Tenure and Social Change in Lower Iraq during late Ottoman Times," in Tarif Khalidi (ed.), Land Tenure and Social Transformation in the Middle East (Beirut: American University of Beirut, 1984): 333-356.

Kaldor-Robinson, Joshua. "The Virtual and the Imaginary: The Role of Diasphoric New Media in the Construction of a National Identity during the Break-up of Yugoslavia," Oxford Development Studies 30.2 (2002): 177-187.

Kaleshi, Hasan. "Le rôle de Chemseddin Sami Frachery dans la formation de deux langues litteraires: Turque et albanaise," Balkcanica 1 (Belgrade, 1970): 187-216.

Kaleshi, Hasan. "Shënime nga e kaluemja e Prizrenit gjatë periudhës turke," Përparimi 7-8 (1961): 489-531.

Kaleshi, Hasan and Hans-Jürgen Kornrumpf, "Das Wilajet Prizren. Beitrag zur Geschichte der türkischen Staatsreform auf dem Balkan im 19. Jahrhundert", Südostforschungen. Internationale Zeitschrift für Geschichte, Kultur und Landeskunde Südosteuropas (München), 26 (1967): 176-238.

Kandiyoti, Deniz. "Gendering the Modern: On Missing Dimensions in the Study of Turkish Modernity," in Sibel Bozdogan and Reşat Kasaba (eds.), Rethinking Modernity and National Identity in Turkey (Seatle: University of Washington Press, 1997)

Karakasidou, Anastasia N. Fields of Wheat, Hills of Blood: Passages to Nationhood in Greek Macedonia, 1870-1990 (Chicago: University of Chicago Press, 1997).

Kark, Ruth. "Changing Patterns of Landownership in Nineteenth-century Palestine: The European Influence," Journal of Historical Geography 10.4 (Oct. 1984): 357-384.

Karpat, Kemal. Ottoman Population, 1830-1914, Demographic and Social Characteristics (Madison: University of Wisconsin Press, 1985).

Karpat, Kemal. The Politicization of Islam: Reconstructing Identity, State, Faith, and Community in the Late Ottoman State (Oxford: Oxford University Press, 2001).

Karpat, Kemal. Studies on Ottoman Social and Political History (Leiden: Brill, 2002).

Kasaba, Reşat A Moveable Empire: Ottoman Nomads, Migrants and Refugees (Seattle: University of Washington Press, 2009).

Kasaba, Reşat. The Ottoman Empire and the World Economy: The Nineteenth Century (Albany: State University of New York Press, 1989).

Kasaba, Reşat. "Open-Door Treaties: China and the Ottoman Empire Compared," New Perspectives on Turkey 7 (1992): 77-89.

Kazgan, Haydar. Osmanlıda Avrupa Finans Kapitali (Istanbul: Yapi Kredi Yayınları, 1995).

Kearney, Richard. Dialogues with Contemporary Continental Thinkers (Manchester: Manchester University Press, 1984).

Kelly, J.B. Britain and the Persian Gulf (Oxford: Clarendon Press, 1968).

Kelly, John D. "Alternative Modernities or an Alternative to 'Modernity': Getting out of the Modernist Sublime," in Bruce M. Knauft (ed.), Critically Modern: Alternatives, Alterities, Anthropologies (Bloomington: Indiana University Press, 2002): 258-286.

Khuri-Makdisi, Ilham. The Eastern Mediterranean and the Making of Global Radicalism, 1860-1914 (Berkeley: University of California Press, 2010).

Kincheoloe, J.L. and P.L. McLaren, "Rethinking Critical Theory and Qualitative Research," in N.K. Denzin and Y.S. Lincoln (eds.) Handbook of Qualitative Research (Thousand Oaks: Sage Press, 1994): 138-157. 
King, Jeremy. Budweisers into Czechs and Germans: A Local History of Bohemian Politics, 1848-1948 (Princeton, NJ: Princeton University Press, 2002).

Koliopoulos, John. Brigands with a Cause: Brigandage and Irredentism in Modern Greece, 1821-1912 (New York: Oxford University Press, 1987).

Koliopoulos, John. Brigands with a Cause: Brigandage and Irredentism in Modern Greece, 1821-1912 (New York: Oxford University Press, 1987).

Kondo, Ahmet. "Kontributi i revistës "Drita-Dituria” për përhapjen e ideve kombëtare dhe të njohurive shkencore (1884-1885)," Studime bistorike 3 (1970): 140-147.

Kondo, Ahmet. Çështja Kombëtare në Faqe të Shtypit të Rilindjes (Tirana: 8 Nëntori, 1982).

Kopytoff, Ivan. (ed.) The African Frontier (Bloomington: Indiana University Press, 1987).

Kour, Zaka H. The History of Aden, 1839-1872 (London: Frank Cass, 1981).

Kraja, Musa. Mati Logoreci (Tirana: 8 Nentore, 1987).

Kuran, Ahmed Bedevi. Inkılap Taribimiz ve Ittihad ve Terakki (Istanbul: Tan Matbaas1, 1948).

Kurmuş, Orhan. Emperyalizmin Türkiye’ye Girişi (Istanbul: Bilim Yayınları, 1974).

Kurşan, Zekeriya. Necid ve Ahsa'da Osmanl Hakimiyeti: Vehhabi Hareketi ve Suud Devleti'nin Ortaya Çıkışı (Ankara: Türk Tarih Kurumu, 1998).

Kühn, Thomas."Clothing the 'Uncivilized': Military Recruitment in Ottoman Yemen," in Suraiya Faroqhi and Christoph K. Neumann (eds.), Ottoman Costumes: From Textiles to Identity (Istanbul: EREM, 2004).

Kühn, Thomas. "Shaping and Reshaping Colonial Ottomanism: Contesting Boundaries of Difference and Integration in Ottoman Yemen, 1872-1919," Comparative Studies of South Asia, Africa and the Middle East 27.2 (2007): 315-331.

Labanca, Nicola. Oltremare: Storia dell'espansione coloniale italiana (Bologna: il Mulino, 2002).

Laclau, Ernest and Chantal Mouffe, Hegemony and Socialist Strategy: Towards a Radical Democratic Politics (London: Verso, 1985).

Landau, Jacob M. The Hejaz Railway and the Muslim Pilgrimage (Detroit: Wayne State University Press, 1971).

Lange-Akhund, Nadine. The Macedonian Question, 1893-1908, from Western Sources (New York: East European Monographs, 1998).

Lenci, Marco. Eritrea e Yemen: Tensioni italo-turche nel mer Rosso, 1885-1911 (Milano: Franco Angeli, 1990).

Lenin, Vladimir I. "Imperialism, The Highest Stage of Capitalism," in Selected Works (Moscow: Progress Publishers, 1963), 667-766.

Leustean, Lucian N. "The Political Control of Orthodoxy in the Construction of the Romanian State, 1859-1918," European History Quarterly 37.1 (January 2007): 61-80.

Lévinas, Emmanuel. Totality and Infinity. An Essay on Exteriority, trans. Alphonso Lingis (Pittsburgh: Duquesne University Press, 1969).

Lévinas, Emmanuel. "Beyond Intentionality," in Alan Montefiore (ed.),Philosophy in France Today (Cambridge: Cambridge University Press, 1983).

Lockman, Zachary. Contending Visions of the Middle East: The History and Politics of Orientalisms (Cambridge: Cambridge University Press, 2004).

Lomnitz-Adler, Claudio. "Nationalism as a Practical System: Benedict Anderson's Theory of Nationalism from the Vantage Point of Spanish America," in Miguel Angel Centeno and Fernando Lopez-Alves (ed.), The Other Mirror: Grand Theory through the Lens of Latin America. (Princeton, NJ: Princeton University Press, 2001): 329-359. 


\section{Bibliography}

Lorimer, J.G. Gazetter of the Persian Gulf, Oman, and Central Arabia, Vol. 1: Historical (Calcutta: Superintendent Government Printing, 1915).

Lyotard, François. The Differend. Phrases in Dispute. Trans. Georges Van Den Abbeele. (Manchester: Manchester University Press, 1988).

MacKenzie, David. The Serbs and Russian Pan-Slavism, 1875-1878 (Ithaca, NY: Cornell University Press, 1967).

Maddison, Angus. Monitoring the World Economy, 1820-1992 (Paris: OECD Development Center Studies, 1995).

Majuru, Adrian. Bucureştiul albanez (Bucureşti: Ararat, 2002).

Makdisi, Ussama. The Culture of Sectarianism, Community, History and Violence in Nineteenth-Century Ottoman Lebanon (Berkeley: University of California Press, 2000).

Makdisi, Ussama. "Ottoman Orientalism," The American Historical Review 107.3 (2002): 768-796.

Maksutoviçi, Gelcu. Istoria Comunitatti Albaneze din Romania (Bucharest: Kriterion, 1992).

Malcolm, Noel. Kosovo: A Short History (New York: Harper Perennial, 1999).

Malcolm, Noel. "Myths of Albanian National Identity: Some Key Elements, as Expressed in the Works of Albanian Writers in America in the Early Twentieth Century," in Stephanie Schwander-Sievers and Bernd J. Fischer (eds), Albanian Identities: Myth and History (London: Hurst, 2002): 70-87.

Malenbaum, Wilfred. The World Wheat Economy, 1885-1939 (Cambridge MA: Harvard University Press, 1953).

Malkki, Liisa H. Purity and Exile: Violence, Memory, and National Cosmology among Hutu Refugees in Tanzania (Chicago: University of Chicago Press, 1995).

Mallon, Florencia. "The Promise and Dilemma of Subaltern Studies: Perspectives from Latin American History," American Historical Review 99.5 (Dec. 1994): 1491-1515.

Mantran, Robert. Histoire de l'Empire ottoman (Paris: Fayard, 2003).

Mardin, Şerif. The Genesis of Young Ottoman Thought: A Study in the Modernization of Turkish Political Ideas (Syracuse, NY: Syracuse University Press, 2000).

Mareci, Harieta and Ştefah Purici, "Under Pressure for Change: Nation State Building and Identity Mutations in Modern Romania (1866-1890)," in Steven G. Ellis and Lud'a Klusáková (eds.), Imagining Frontiers, Contesting Identities (Rome: Edizioni Plus, 2007): 175-188.

Massumi, Brian. Parables for the Virtual: Movement, Affect, Sensation (Durham, N.C.: Duke University Press, 2002).

Marston, Thomas E. Britain's Imperial Role in the Red Sea Area: 1800-1878 (Hamden, CT: Shoe String Press, 1961).

McCabe, Ina Baghdiantz, Gelina Harlaftis and Ioanna Peplasis Minoglou (eds.), Diaspora Entrepreneurial Networks: Four Centuries of History (Oxford: Berg, 2005).

McCarthy, Justin. Death and Exile: The Ethnic Cleansing of Ottoman Muslims, 1821-1922 (Princeton, NJ: The Darwin Press, 1995).

McGrew, William W. Land and Revolution in Modern Greece, 1800-1881 (Kent, $\mathrm{OH}$ : Kent State University Press, 1985).

McMeekin, Sean. The Berlin-Baghdad Express: The Ottoman Empire and Germany's Bid for World Power (Cambridge, MA: Belknap Press, 2010).

Medlicott, William N. The Congress of Berlin and After: A Diplomatic History of the Near Eastern Settlement, 1878-1880 (London: Methuen \& Co. ltd., 1938).

Meeker, Michael E. A Nation of Empire: The Ottoman Legacy of Turkish Modernity (Berkeley: University of California Press, 2002). 
Mehta, Uday Singh. Liberalism and Empire: A Study in Nineteenth-Century British Liberal Thought (Chicago: Chicago University Press, 1999).

Mignolo, Walter D. Local Histories/Global Designs: Coloniality, Subaltern Knowledges, and Border Thinking (Princeton, NJ: Princeton University Press, 2000).

Miran, Jonathan. Red Sea Citizens: Cosmopolitan Society and Cultural Change in Massawa (Bloomington: Indiana University Press, 2009).

Mitchell, Timothy. Colonising Egypt (Berkeley: University of California Press, 1988).

Mitchell, Timothy. “The Stage of Modernity,” in Timothy Mitchell (ed.), Questions of Modernity (Minneapolis: University of Minnesota Press, 2000): 1-34.

Mitchell, Timothy. Rule of Experts: Egypt, Techno-Politics, Modernity. (Berkeley: University of California Press, 2002).

Morson, Gary S. Narrative and Freedom: The Shadows of Time (New Haven: Yale University Press, 1996).

Muri, Khalif Abd al-'Azim Sayyid. Tarikh al-Bahriyya al-Tijariyyah al-Misriyya, 1854-1879 (Cairo: al-Hiyyah al-Misriyya al-alimiyya lil-kitab, 1993).

Myderrizi, Osman. "Letërsia shqipe me alfabetin arab," Buletin për Shkencat Shoqërore 2 (1955): 148-155.

Myzyri, Hysni. Arsimi Kombëtar Shqiptar (1908-1912) (Pristinë: Enti i Teksteve dhe i Mjeteve Mësimore i Kosovës, 1996).

Myzyri, Hysni. Shkolla Normale e Elbasanit (1909-1912) (Tiranë: NP, 2004).

Naçi, Nuçi. Korça dhe fshatrat për çark (Sofia: Mbrothësia, 1901).

Naçi, Stavri N. Pashalleku i Shkodrës nën Sundimin e Bushatllijve në Gjysmën e Dytë të Shekullit të XVIII (1757-1796) (Tiranë: Universiteti Shtetëror i Tiranës, 1964).

Naço, Nikolla N. Viitorul Romanismului in Balcan: Scisoare Deschisa (Bucuresti: Tipografia G.A. Lazareanu, 1905).

Nadri, Ghulam. Eighteenth-Century Gujarat: The Dynamics of its Political Economy, 1750-1800 (Leiden: Brill, 2008).

Nakash, Yitzhak. "The Conversion of Iraq's Tribes to Shi'ism," IJMES 26 (1994): 443-463.

Ngugi, Thiong'o wa. Decolonising the Mind: The Politics of Language in African Literature (Portsmouth, N.H.: Heinemann, 1986).

Nopcsa, Franz. Das katholische Nordalbanie (Wien: Holzhausen, 1907).

Nopcsa, Franz. Aus Šala und Klementi. Albanische Wanderungen (Sarajevo: D.A. Kajon, 1910).

Noradounghian, Gabriel Efendi. Recueil d'actes internationaux de l'Empire Ottoman, 4 vols. (Paris: F. Pichon, 1902).

O'Brien, Patrick K. "The Costs and Benefits of British Imperialism, 18461914,"Past and Present 120 (1988): 163-200.

Ochsenwald, William. The Hijaz Railroad (Charlottesville: The University of Virginia Press, 1980).

Ochsenwald, William. "The Commercial History of the Hijaz Vilayet, 18401908," Arabian Studies 6 (1982): 57-77.

O'Fahey, R.S., A. Hofheinz, and Bernd Radtke, "The Khatmiyya Tradition," in R.S.O'Fahey (ed.), Arabic Literature of Africa, I: The Writings of Eastern Sudanic Africa to c. 1900 (Leiden: Brill, 1994): 178-227.

Okyar, Osman. "A New Look at the Problem of Economic Growth in the Ottoman Empire (1800-1914)," The Journal of European Economic History 16.1 (1987): 7-50.

Onley, James. The Arabian Frontier of the British Raj: Merchants, Rulers, and the British in the Nineteenth Century Gulf (London: Oxford University Press, 2008).

Orhonlu, Cengiz. Osmanlı Imperatorluğunda Derbend Teşkilatı (Istanbul: Istanbul Üniversitesi Edibiyat Fakultesi Yayınları, 1990). 


\section{Bibliography}

Ortalli, Gherardo and Oliver Jens Schmitt (eds.), Balcani accidentali, Adriatico e Venezia fra XIII et XVIII secolo (Vienna: Verlag der Osterreichischen Akademie der Wissenschaften, 2009).

Owen, Roger. The Middle East in the World Economy (London: I.B. Tauris, 1993).

Owen, Roger and Șevket Pamuk (eds.) A History of the Economies of the Middle East in the Twentieth Century (London: I.B. Tauris, 1998).

Özkaya, Yücel. Osmanlı Imparatorluğu'nda Ayanlık (Ankara: Türk Tarih Kurumu, 1994).

Pagden, Anthony. Peoples and Empires: A Short History of European Migration, Exploitation, and Conquest from Greece to the Present (New York: Modern Library, 2001).

Palairet, Michael R. The Balkan Economies, 1800-1914: Evolution without Development (Cambridge: Cambridge University Press, 1997).

Palmer, Bryan D. Descent into Discourse: The Reification of Language and the Writing of Social History (Philadelphia: Temple University Press, 1990).

Pamuk, Şevket. "The Ottoman Empire in the "Great Depression" of 1873-1896," Journal of Economic History 44.1 (1984): 107-118.

Pamuk, Şevket. The Ottoman Empire and European Capitalism, 1820-1913, Trade, Investment and Production (Cambridge: Cambridge University Press, 1987).

Pamuk, Şevket. "Appendix: Money in the Ottoman Empire, 1326-1914," in Halil Inalcik and D. Quataert (eds.) An Economic and Social History of the Ottoman Empire, 1300-1914 (Cambridge: Cambridge University Press, 1994): 947-980.

Pamuk, Şevket. A Monetary History of the Ottoman Empire (Cambridge: Cambridge University Press, 2000).

Pamuk, Şevket. "Prices in the Ottoman Empire, 1469-1914," IJMES 36.3 (2004): 451-468.

Panaite, Viorel. The Ottoman Law of War and Peace: The Ottoman Empire and Tribute Payers (New York: Columbia University Press, 2000).

Pankhurst, Richard. "The History of Currency and Banking in Ethiopia and the Horn of Africa from the Middle Ages to 1935," Ethiopian Observer 8 (1965): 358-408.

Pankhurst, Richard. “The Advent of the Maria Theresa Dollar in Ethiopia, Its Effect on Taxation and Wealth Accumulation, and Other Economic, Political and Cultural Implications," Northeast African Studies 1.3 (1979-1980): 19-48.

Panzac, Daniel. "International and Domestic Maritime Trade in the Ottoman Empire during the $18^{\text {th }}$ Century," IJMES 24.2 (1992): 189-206.

Papajani, Adrian. "Veprimtaria Ekonomike e Firmave Tregtare Çoba dhe Bianki," Arkivi Shqiptar 2 (2001): 19-28.

Parvus (A. Helphand), Türkiye'nin Can Damarı: Devlet-i Osmaniyyenin Borçları ve Islahı (Istanbul: Türk Yurdu Kütübhanesi, 1330 [1912]).

Perry, Duncan M. The Politics of Terror: The Macedonian Liberation Movements, 1893-1903 (Durham, NC: Duke University Press, 1988).

Petmezas, Socrates D. "Bridging the Gap: Rural Macedonia from Ottoman to Greek Rule (1900-1920)," in Lorans Tanatar Baruh and Vangelis Kechriotis (eds.), Economy and Society on Both Shores of the Aegean (Athens: Alpha Bank Historical Archives, 2010): 355-395.

Phillip, Thomas. Acre (New York: Columbia University Press, 2002).

Poggi, Gianfranco. The State: Its Nature, Development and Prospects (Palo Alto: Stanford University Press, 1990).

Polanyi, Karl. The Great Transformation: The Political and Economic Origins of Our Time (Boston: Beacon Press, 2001).

Pollera, Alberto. Le popolazione indigene dell'Eritrea (Bologna: Capelli, 1935). 
Poulantzas, Nicos. Pouvoir politique et classes sociales 2 vols. (Paris: Maspero, 1975).

Prenkaj, Marjan. Prizreni dhe Rrethina në Shekullin XIX dhe në Fillim te Shekullit XX (Prishtinë: Instituti i Historisë, 1998).

Prifti, Kristaq. Le Mouvement national albanais de 1896 à 1900: La Ligue de Pejë (Tiranë: Akademia Historike, 1989).

Prifti, Kristaq. Dervish Hima (1872-1928) (Tirana: 8 Nentori, 1987).

Purvis, Martin. "Between Late-Lasting Empire and Late-Developing Nation-State: A Triestine Perspective on City-State Relations," Social \& Cultural Geography 10.3 (May 2009): 299-317.

Puryear, V.J. International Economics and the Diplomacy of the Near East: A Study of British Commercial Policy in the Levant, 1834-1853 (Stanford: Stanford University Press, 1935).

Quataert, Donald. "Dilemma of Development: The Agricultural Bank and Agricultural Reform in Ottoman Turkey, 1888-1908," IJMES 6 (1975): 210-227.

Quataert, Donald. Social Disintegration and Popular Resistance in the Ottoman Empire, 1881-1908: Reactions to European Economic Penetration (New York: New York University Press, 1983).

Quataert, Donald. "The Ottoman Handicrafts Industry in the Age of European Industrial Hegemony, 1800-1914," Review 11.2 (1988): 160-178.

Quataert, Donald. Manufacturing and Technology Transfer in the Ottoman Empire, 1800-1914 (Istanbul: ISIS Press, 1992).

Quataert, Donald. "The Age of Reforms," in Halil Inalcik and Donald Quataert, (eds.), An Economic and Social History of the Ottoman Empire (Cambridge: Cambridge University Press, 1994): 759-933.

Quataert, Donald. The Ottoman Empire, 1700-1922 (Cambridge: Cambridge University Press. 2000).

Quataert, Donald. "Labor History and the Ottoman Empire, c. 1700-1922," International Labor and Working-Class History 60 (Fall 2001): 93-109.

Quataert, Donald. Miners and the State in the Ottoman Empire: The Zonguldak Coalfield, 1822-1920 (New York: Berghahn Books, 2006).

Raça, Shkëlzen. Marrëdhëniet Shqiptaro-Greke, 1829-1881 (Prishtinë: Instituti i Historisë, 1990).

Rahimi, Shukri. Lufta e Shqiptarëve për Autonomi, 1897-1912 (Prishtinë: Enti i Teksteve dhe i Mjeteve Mësimore i Krahines Socialiste Autonome të Kosovës, 1978).

al-Rashid, Zamil Sa'udi Relations with Eastern Arabia and Uman. 1800-1870 (London: Luzac, 1981).

Raşid, Ahmed. Tarih-i Yemen ve San'a' 2 vols. (Istanbul: Basiret Matbassı, 1291/1874).

Reid, James J. Crisis of the Ottoman Empire: Prelude to Collapse, 1839-1878 (Stuttgart: Franz Steiner Verlag, 2000).

Reinkowski, Maurus. Die Dinge der Ordnung: Eine vergleichende Untersuchung über die osmanische Reformpolitik im 19. Jahrhundert (München: R. Oldenbourg Verlag München, 2005).

Renan, Ernest. "What is a Nation?" in Homi K. Bhabha (ed.), Nation and Narration (New York: Routledge, 1990): 8-22.

Rich, Norman. Great Power Diplomacy: 1814-1914 (New York: McGrawHill, 1992).

Rihani, Amin. Around the Coasts of Arabia (London: Constable, 1930).

Rodkey, F.S. The Turco-Egyptian Question in the Relations of England, France, and Russia, 1832-1841 (Urbana: University of Illinois Press, 1921).

Rodkey, F.S. "Lord Palmerston and the Rejuvenation of Turkey, 1830-1841," Journal of Modern History, I (1929), 570-93 and II (1930), 193-225. 
Rogan, Eugene. Frontiers and State in the Late Ottoman Empire: Transjordan, 1850-1921 (Cambridge: Cambridge University Press, 2002).

Rosaldo, Renato. Culture and Truth: The Remaking of Social Analysis (Boston: Beacon Press, 1993).

Rosenberg, Hans. "Political and Social Consequences of the Great Depression of 18731896 in Central Europe," The Economic History Review, XIII (1943): 58-73.

Roshwald, Aviel. Ethnic Nationalism and the Fall of Empires: Central Europe, Russia and the Middle East, 1914-1923 (London: Routledge, 2001).

Roudometoff, Victor. Nationalism, Globalization and Orthodoxy: The Social Origins of Ethnic Conflict in the Balkans (New York: Greenwood, 2001).

Safran, William. "Diasporas in Modern Societies: Myths of Homeland and Return," Diaspora 1.1 (1991): 83-89.

Sahlins, Peter. Boundaries: The Making of France and Spain in the Pyrenees (Berkeley: University of California Press, 1991).

Said, Edward. Orientalism (New York: Pantheon, 1978).

Said, Edward. "Orientalism Reconsidered," in Francis Barker et al. (ed.), Europe and Its Others, Vol. 1 (Colchester: University of Essex, 1985).

Said, Edward. "Orientalism Reconsidered," Race \& Class: A Journal for Black and Third World Liberation 27 (1985): 1-15.

Said Paşa, Said Paşa'nin Hatıratı 2 vols. (Istanbul: Sabah Matbaası, 1328 [1910]).

Salzmann, Ariel. "An Ancien Regime Revisited: Privatization and Political Economy in the Eighteenth-Century Ottoman Empire," Politics and Society 21.4 (1993): 393-424.

Salzmann, Ariel. Tocqueville in the Ottoman Empire: Rival Paths to the Modern State (Leiden: E. J. Brill, 2004).

Sarkar, Sumit. Beyond Nationalist Frames: Postmodernism, Hindu Fundamentalism, History (Bloomington: Indiana University Press, 2002).

Sarup, Madan. An Introductory Guide to Post-structuralism and Postmodernism (Athens: University of Georgia Press).

Sathisan, Dinesh. "Speaking for the Diaspora: Tamil Newspapers in Malaya and Singapore as Instruments of Modernity, Protection, Reform and Change, 19301940," The Heritage Journal 4 (2009): 74-96.

Schirò, Giuseppe. Gli albanesi e la questione balcanica (Napoli: A spese dell'editore Ferd. Bideri, 1904).

Schwandner-Sievers, Stephanie. and Bernd J. Fischer (eds.), Albanian Identities: Myth and History (Bloomington: Indiana University Press, 2002).

Scott, David. "Colonial Governmentality," Social Text 43 (Fall 1995): 191-220.

Scott, James C. Seeing Like the State: How Certain Schemes to Improve the Human Condition Have Failed (New Haven: Yale University Press, 1999).

Scott, James C. The Art of Not Being Governed: An Anarchist History of Upland Southeast Asia (New Haven: Yale University Press, 2009).

Scott, Joan W. "History Writing as Critique," in Keith Jenkins, Sue Morgan and Alun Munslow, (eds.), Manifestos for History (London: Routledge, 2007): 19-38.

Seigel, Micol. "Beyond Compare: Comparative Method after the Transnational Turn," Radical History 91 (2005): 62-90.

Sewell, William. "Historical Events as Transformations of Structures: Inventing Revolution at the Bastille," Theory and Society 25 (1996): 841-888.

Shaw, Stanford J. Between Old and New: The Ottoman Empire under Sultan Selim III, 1789-1807 (Cambridge: Harvard University Press, 1971).

Shaw, Stanford J. "The Nineteenth-Century Ottoman Tax Reforms and Revenue System,” IJMES, 6.3 (1975): 421-459.

Shaw, Stanford J. and Ezel Kural Shaw, History of the Ottoman Empire and Modern Turkey 2 vols, (Cambridge: Cambridge University Press, 1987). 
Shohat, Elias. "Notes on the 'post-colonial,'” in Padmini Mongia (ed.), Contemporary Postcolonial Theory: A Reader (London: Arnold, 1996): 321-334.

Shtjefni, Kolë. Mirdita: Doke dhe Zakone (Tiranë: Albin, 1998).

Shpuza, Gazmend. Në Vazhdën e Gjumimeve për Epokën e Rilindjes Kombëtare (Tiranë: TOENA, 1997).

Shukri, Muhammad Fu'ad. Al-hukm al-Misri fi al-Sudan, 1820-1885 (Cairo: Dar al-fikr al 'arabi, 1947).

Skendi, Stavro. The Albanian National Awakening, 1878-1912 (Princeton, NJ: Princeton University Press, 1967).

Skiotis, Dennis. "From Bandit to Pasha: First Steps in the Rise to Power of Ali of Tepelen, 1750-1784,” IJMES 2 (1971): 219-244.

Skiotis, Dennis. "The Greek Revolution: Ali Pasha's Last Gamble," in Nikoforos Diamandouros, John Anton, Peter Topping and John Petropoulos (eds.), Hellenism and the First Greek War of Liberation (1821-1830): Continuity and Change, (Thessaloniki: Institute for Balkan Studies, 1976): 97-109.

Skoulidas, Elias. "The Perception of the Albanians in Greece in the 1830s and '40s: The Role of the Press," in Stephanie Schwandner-Sievers and Bernd J. Fischer (eds), Albanian Identities: Myth and History (London: Hurst, 2002): $172-181$.

Slot, B.J. Mubarak al-Sabah: Founder of Modern Kuwait, 1896-1915 (London: Arabian Publishing, 2005).

Smith, Neil. and Cindi Katz, "Grounding Metaphor: Towards a Spatialized Politics," in Michael Keith and Steve Pile (eds.), Place and the Politics of Identity (New York: Routledge, 1993): 67-83.

Sohrabi, Nader. "Revolutions as Pathways to Modernity," in Julia Adams, Elisabeth S. Clemens and Ann Shola Orloff (eds.), Remaking Modernity: Politics, History and Sociology (New York: Duke University Press, 2005): 300-332.

Soja, Edward W. Thirdspace: Journeys to Los Angeles and Other Real-and-Imagined Places (New York: Wiley-Blackwell, 1996).

Somel, Selçuk Aksin. The Modernization of Public Education in the Ottoman Empire, 1839-1908: Islamization, Autocracy and Discipline (Leiden: Brill, 2001).

Sowards, Steven W. Austria's Policy of Macedonian Reform (Boulder: East European Monographs, 1989).

Sperber, Jonathan. The European Revolutions, 1848-1851 (Cambridge: Cambridge University Press, 2005).

Spulber, Nicholas. Changes in the Economic Structure of the Balkans, 1860-1960 (Berkeley: University of California Press, 1963).

Shpuza, Gazmend. Në Vazhdën e Gjurmimeve për Epokën e Rilindjes Kombëtare (Tiranë: TOENA, 1997).

Stamatopoulos, Dimitrios. "From Millets to Minorities in the $19^{\text {th }}$-Century Ottoman Empire: An Ambiguous Modernization," in Ann Katherine and Steven G. Ellis (eds.), Citizenship in Historical Perspective (Pisa: Pisa University Press, 2006): 253-273.

Stathis, Pavlos. "From Klepths and Armatoloi to Revolutionaries," in A. Anastasopoulos and E. Kolovos (eds.), Ottoman Rule and the Balkans, 1760-1850: Conflict, Transformation, Adaptation (Rethymno: University of Crete, 2007): 167-179.

Stewart, Charles. (ed.) Creolization: History, Ethnography, Theory (Walnut Creek, CA: Left Coast Press, 2007).

Stojanović, Mihailo D. The Great Powers and the Balkans, 1875-1878 (Cambridge: Cambridge University Press, 1939).

Stoler, Ann L. Race and the Education of Desire: Foucault's History of Sexuality and the Colonial Order of Things (Durham, NC: Duke University Press, 1995).

Streusand, Douglas E. Islamic Gunpowder Empires: Ottomans, Safavids, and Mughals (Boulder: Westview Press, 2010). 


\section{Bibliography}

Sudi, Süleyman. Defter-i Muktesid 2 volumes (Dersaadet: Mahmud Bey Matbaası, 1306 [1889]).

Suvla, Refii Ș. "The Ottoman Debt, 1850-1939," in Charles Issawi (ed.), The Economic History of the Middle East, 1800-1914 (Chicago: Chicago University Press, 1966): 94-106.

Swain, J.E. The Struggle for the Control of the Mediterranean prior to 1848: A Study of Anglo-Turkish Relations (Cambridge: Harvard University Press, 1933).

Şakul, Kahraman. "Ottoman Attempts to Control the Adriatic Frontier in the Napoleonic Wars," Proceedings of the British Academy 156 (2009): 253-270.

Şimşir, Bilal N. Rumeli'den Türk Goçleri, 3 vols (Ankara: Türk Tarih Kurumuyu, 1989).

Talhami, Ghada H. Suakim and Massawa under Egyptian Rule, 1865-1885 (Northhampton, MA: University Press of America, 1987).

Tatsios, Theodore G. The Megali Idea and the Greek-Turkish War of 1897: The Impact of the Cretan Problem on Greek Irredentism, 1866-1897 (New York: Columbia University Press, 1984).

Temo, Ibrahim. Doktor Ibrahim Temo Ittihad ve Terakki Cemiyetinin Teșekkülü ve Hidemati Vataniye ve Inkılâbi Milliye Dair Hatıratım (Mecidiye, 1939).

Ternon, Yves. Empire Ottoman: Le déclin, la chute, l'effacement (Paris Editions du Félin, 2005).

Tezcan, Baki. The Second Ottoman Empire: Political and Social Transformation in the Early Modern World (Cambridge: Cambridge University Press, 2010).

Tignor Robert L. and Samuel Moreh (translator), Napoleon in Egypt: Al-Jabarti's Chronicle of the French Occupation, 1798 (Princeton, NJ: Markus Wiener Publishers, 2005).

Tilly, Charles. Coercion, Capital and European States, AD 990-1990 (Oxford: Blackwell, 1990).

Tilly, Charles. The Politics of Collective Violence (Cambridge: Cambridge University Press, 2003).

Tilly, Charles. Identities, Boundaries, and Social Ties (Boulder, CO: Paradigm, 2005).

Todorova, Maria. Imagining the Balkans (New York: Oxford University Press, 1997).

Tokay, Gül. Makedonya Sorunu: Jön Türk Ibtilalinin Kökenleri (1903-1908) (Istanbul: AFA Yayınları, 1995).

Toumarkine, Alexandre. Les Migrations des populations musulmanes balkaniques en Anatolie (1876-1913) (Istanbul: Isis Press, 1995).

Trimingham, John S. Islam in Ethiopia (London: Cass, 1965).

Trix, Frances. "The Stamboul Alphabet of Shemseddin Sami Bey: Precursor to Turkish Script Reform,” IJMES 31.2 (1999): 255-272.

Trocki, Carl A. Opium and Empire: Chinese Society in Colonial Singapore, 18001910 (Ithaca, NY: Cornell University Press, 1990).

Trocki, Carl A. Opium, Empire and the Global Political Economy: A Study of the Asian Opium Trade, 1750-1950 (London: Routledge, 1999).

Trouillot, Michel-Rolph. Silencing the Past: Power and the Production of History (Boston: Beacon Press, 1995).

Trouillot, Michel-Rolph. "The Otherwise Modern: Caribbean Lessons from the Savage Slot," in Bruce M. Knauft (ed.), Modern Alternatives, Alterities, Anthropologies (Bloomington: Indiana University Press, 2002): 220-237.

Tsing, Anne Lowenhaupt. Friction: An Ethnography of Global Connection (Princeton, NJ: Princeton University Press, 2004).

Tuan, Yi-Fu. Space and Place: The Perspective of Experience (Minneapolis: University of Minnesota Press, 1977).

Turnbull, David. Maps are Territories: Science Is an Atlas (Chicago: University of Chicago Press, 1993). 
Uka, Sabit. Dëbimi i Shqiptarëve nga Sanxhaku $i$ Nishit dhe vendosja e tyre në Kosovë, 1878-1912, 4 vols. (Prishtine: Verana, 2004).

du Velay, Andre. Essai sur l'histoire financière de la Turquie (Paris: A. Rousseau, 1903).

Vickers, Miranda. The Albanians: A Modern History (London: I.B. Tauris, 2001).

Vishesella, Nazmi. Vuajtjet e Kombit Shqiptarë-Muhaxhirëve me Shikuj (Ferizaj: DinoGraf 2005).

Vitalis, Robert. "On the Theory and Practice of Compradors: The Role of "Abbud Pasha in the Egyptian Political Economy," IJMES 22 (1990): 291-315.

Wallerstein, Immanuel. "The Ottoman Empire and the Capitalist World-Economy: Some Questions for Research,” Review II.3 (1979): 389-399.

Wallerstein, Immanuel. The Modern World-System III: The Second Era of Great Expansion of the Capitalist World-Economy, 1730s-1840s (New York: Academic Press, 1988).

Wandruszka, Silvio Furlani-A. Austria e Italia. Storia a due voci (Bologna: Cappelli, 1974).

al-Wasi'i, 'Abd al-Wasi'. Ta'rikh al-Yaman (Cairo: al-Matba'a al-Salafiyya, 1928).

Wassa Effendi, La verité sur l'Albanie et les Albanais, étude historique et critique (Paris: Impr. de la Société anonyme de publications périodiques 1879).

Watenpaugh, Keith D. Being Modern in the Middle East: Revolution, Nationalism, Colonialism, and the Arab Middle Class (Princeton, NJ: Princeton University Press, 2006).

Watts, Sheldon. "From Rapid Change to Stasis: Official Responses to Cholera in British-Ruled India and Egypt: 1860-1921." Journal of World History 12.2 (2001): 321-374.

White, Hayden. The Content of the Form: Narrative Discourse and Historical Representation (Baltimore: Johns Hopkins University Press, 1990).

Wiebe, Robert. The Search for Order, 1877-1920 (Westport, CT: Greenwood Press, 1967).

Wilson, Jon E. "Subjects and Agents in the History of Imperialism and Resistance," in Charles Hirschkind and David Scott (eds.) Powers of the Secular Modern: Talal Asad and His Interlocutors (Palo Alto: Stanford University Press, 2006): 180-205.

Winkler, Max. Foreign Bonds: An Autopsy (Philadelphia: Roland Swain Co., 1933).

Winichakul, Thongchai. Siam Mapped: A History of the Geo-Body of a Nation (Honolulu: University of Hawaii Press, 1994).

Wolfe, Patrick. Settler Colonialism and the Transformation of Anthropology: The Politics and Poetics of an Ethnographic Event (London: Cassel, 1999).

Wolff, Larry. Inventing Eastern Europe: The Map of Civilization on the Mind of the Enlightenment (Palo Alto: Stanford University Press, 1996).

Xoxi, Koli. Lufta e Popullit Grek Për Pavarësi: Kontributi Shqiptar (Tiranë: Shtëpia Botuese 'Enciklopedike,'1991).

Yapp, Malcolm E. "The Legal and Historical Basis of the British Position in the Persian Gulf," St. Anthony's Papers, No. 4: Middle Eastern Affairs (London, 1959): 119-140.

Yosmaoğlu, Ipek K. "Constructing National Identity in Ottoman Macedonia," in William Zartman (ed.), Understanding Life in the Borderlands, 160-188.

Young, Robert. White Mythologies: Writing History and the West (New York: Routledge, 1990).

Zabara, Muhammad b. Muhammad. A'immat al-Yaman bi-l-qarn al-rabi' 'ashar 2 vols. (Cairo: al-Matba'a al-Salafiyya, 1956). 


\section{Bibliography}

Zartman, I. William. Understanding Life in the Borderlands: Boundaries in Depth and in Motion (Athens: University of Georgia Press, 2010).

Zens, Robert. "Pasvanoğlu Osman Paşa and the Paşalık of Belgrade, 1791-1807," International Journal of Turkish Studies 8.1\&2 (2002): 89-104.

Žižek, Slavoj. The Sublime Object of Ideology (London Verso, 1989).

Zhou, Min. "Revisiting Ethnic Entrepreneurship: Convergencies, Controversies, and Conceptual Advancements," International Migration Review 38.3 (Fall 2004): 1040-1074.

Zolberg, Aristide R., Astri Suhrek, and Sergio Aguayo, Escape from Violence: Conflict and the Refugee Crisis in the Developing World (New York: Oxford University Press, 1992).

Zubaida, Sami. (ed.) Race and Racialism (London: Tavistock Publications, 1970). Zürcher, Erik J. Turkey: A Modern History (London: I.B. Tauris, 1997). 